\title{
A Contribution to Pollen Rain Characterization in Forest-Savanna Mosaics of the Venezuelan Guayana and Its Use in Vegetation Reconstructions from Sedimentary Records
}

\author{
Leal Alejandra ${ }^{1 *}$, Bilbao Bibiana ${ }^{1}$, Berrío Juan Carlos ${ }^{2}$ \\ ${ }^{1}$ Department of Environmental Studies, Universidad Simón Bolívar, Sartenejas. Edo., Caracas, Venezuela; ${ }^{2}$ Department of Geo- \\ graphy, University of Leicester, Leicester, UK. \\ Email: *avleal@usb.ve
}

Received May $18^{\text {th }}, 2013$; revised June $17^{\text {th }}, 2013$; accepted July $10^{\text {th }}, 2013$

Copyright (C) 2013 Leal Alejandra et al. This is an open access article distributed under the Creative Commons Attribution License, which permits unrestricted use, distribution, and reproduction in any medium, provided the original work is properly cited.

\begin{abstract}
The main results of a study of pollen representation in surface soils from different plant communities in the upland savannas of Guayana were presented. The representation of savanna herb pollen mainly belonging to the Poaceae and $\mathrm{Cy}-$ peraceae was high in open communities such as fernlands, grasslands and Mauritia palm swamps, but decreased as vegetation structure became more closed and woody; from savanna-forest borders to secondary forests and lastly, evergreen montane forests; mimicking the gradient of vegetation openness observed in living plant communities. Thus, the proportion of savanna herb pollen in herbaceous communities: swamps, fernlands and grasslands, reached over $80 \%$ and arboreal pollen contributed less than $10 \%$. This ratio changed in savanna-forest borders where savanna herb pollen decreased to $60 \%$ or less and the proportion of arboreal pollen rose to $30 \%$ or higher. Lastly, in forest soils, pollen abundances from trees (Dimorphandra, Protium, Schefflera), shrubs (Miconia and other Melastomataceae) and lianas contributed higher than $60 \%$ of the pollen sum, even in open gallery forests and fallows. The lack of pollen from cassava, the main crop in the forests of the region, at these sites was remarkable. The ordination of sediment samples from 4 records from the Late Holocene with respect to the soil surface samples studied, showed that the characterization of pollen rain was useful for identifying long-term compositional and structural changes in the sedimentary records, thus providing objective indicators for the interpretation of past vegetation structure.
\end{abstract}

Keywords: Pollen Representation; Savanna-Forest Dynamics; Upland Guayana; Gran Sabana; Poaceae Pollen

\section{Introduction}

Several paleocological studies have been carried out in the upland savannas of Guayana, in Southeast Venezuela, over the last few years [1-7]. However, the interpretation of palynological data has been supported by few pollen rain studies (see for example references $[8,9]$ ). Since the main goal of paleoecological studies in the region is to understand the factors influencing the apparently anomalous coexistence between evergreen forest and treeless savannas, the palynological characterization of forest, savannas, and the transitional communities between them is strongly required. However, up until now, a broad study of modern pollen deposition patterns among different plant communities in the current vegetation mosaic has

\footnotetext{
"Corresponding author.
}

been lacking. Furthermore, many important plant associations in the Guayana uplands have not been characterized from the palynological point of view, including gallery forests and montane forests on welldrained soils, which represent more than $70 \%$ of regional plant cover [10].

In the last decades, the necessity of improving the paleoecological interpretation of data from the neotropical lowlands, uplands and highlands, has led to an increasing number of pollen rain studies, some of the most notable being the study of pollen representation in soils from Costa Rican ecosystems by reference [11], studies done on pollen rain along altitudinal gradients [12-16] and those undertaken by references $[17,18]$ in coastal communities. Published analyses of pollen production-dispersal in tropical rainforests, deciduous forests and sa- 
vannas of Central America, the Amazon and Orinoco Basins have suggested ways for improving the interpretation of pollen abundance from tropical plant genera and families [19-30]. Likewise, the compilation of pollen types present in different regions and environments in a unique Latin American Pollen Data Base (LAPD) has proved a valuable tool for the interpretation of the occurrence of pollen-types, and their relation with environmental constraints [31]. However, the usefulness of results from these initiatives in the interpretation of pollen assemblages in a given region is sometimes limited, as these studies have still not managed to cover the impressively high diversity of plant associations found in the Neotropics. This is especially true of the Guayana uplands, where the unique geology and flora of the area has made studies of plant ecology difficult to compare with data from similar studies performed in other parts of the Neotropics.

Here we present the results of a study of pollen representation done in 30 plant communities in the upland savannas of Guayana, as a contribution for the development of tools and indicators for the study of forest-savanna dynamics. Although we did not cover the total diversity of plant communities present in the area, some communities never studied in earlier initiatives, such as evergreen terra firme forests, evergreen gallery forests, slash and burn fallows, savanna/forest borders, and fernlands, were included. We included human-made forest gaps in the study in order to look for palynological indicators of human activities. The ordination of samples from soil profiles and sediment cores with respect to the modern samples showed that pollen rain characterization was useful for the identification of long-term compositional and structural changes in the sedimentary records, thus providing us with objective indicators for the interpretation of long-term vegetation changes.

\section{Study Area}

\subsection{Location and Environmental Setting}

The upland savannas of Guayana are located in Southeast Venezuela, between $4^{\circ} \mathrm{N}-6^{\circ} \mathrm{N}$ (Figure 1). Geologically they are situated on the Precambrian Guayana Shield that constitutes one of the oldest basement rock formations in the world. This plateau, between 800 and 1.500 masl in the southeast portion of the Canaima National Park, is known as Gran Sabana, and is famous worldwide for the presence of prominent sandstone Table Mountains (locally called tepuis).

The climate in the Gran Sabana plateau is humid submesothermic, with mean air temperatures between $17^{\circ} \mathrm{C}$ $24^{\circ} \mathrm{C}$ and mean annual rainfall around $1.600-4.000 \mathrm{~mm}$ $[32,33]$. The temporal rainfall pattern is unimodal, generally with a short, mild dry season from January to
March, coinciding with the southward migration of the ITCZ [32].

The main parent materials in the Gran Sabana originnate from sedimentary rocks produced over the geological eras by the weathering, leaching and erosion of the Precambrian basement rocks. These last are made up of the ancient sandstones of the Roraima Group, which produces very acidic (pH $3.5-4.5)$ and cation depleted soils, rich in aluminum complexes [34,35].

\subsection{Present Vegetation and Human Occupation in the Study Area}

Although the principal vegetation types in the region are evergreen montane and gallery forests, in the Gran Sabana savannas represent almost $1 / 3$ of total plant cover [10]. In some areas, such as the eastern sector, these savannas constitute the main vegetation matrix, and forests together with other plant associations are patchily distributed (Figure 2(A)).

The Gran Sabana forms a part of the ancestral lands of the Pemon Amerindians, whose main activities are slash and burn agriculture and hunting, using fire extensively in all their activities. Recent evidence indicates that the region may have been occupied by humans for millennia $[6,7]$. Human use of forests creates a large variety of secondary woody formations such as fallows of different ages after slash and burn agriculture. In addition, the Pemon burn the savannas systematically [36,37], promoting heterogeneity in the structure of the vegetation through the creation of mosaic-patch-burning [38,39].

\subsubsection{Forests}

According to the literature, regional forests can be classified as mature tall forests, secondary forests and "matorrales" $[40,41]$. Trees in tall forests are usually about $30 \mathrm{~m}$ high, in secondary forests around $15-20 \mathrm{~m}$ high, and below $15 \mathrm{~m}$ in the "matorrales" [40,41]. Gallery forests are also very important in the area, forming thin, but not always continuous, belts along rivers. These types of forests are made up of medium high trees (around $15 \mathrm{~m}$ high) and are relatively open (with a high density of lianas and epiphytic plants). All forest formations are evergreen.

Vegetation composition seems to be similar between forests, although dominance and structure change according to the degree of disturbance and other features, such as slope, soil quality and the presence of rivers and streams [40]. Members of the Lauraceae family are generally dominant (mainly Ocotea species), as are those of the Fabaceae (Dimorphandra macrostachya, Tachigali guianensis, Alexa sp.), Annonaceae (Anaxagorea sp.), Flacourtiaceae (Eucearea nitida), Chrisobalanaceae (Hirtella sp., Licania sp.), Malpighiaceae (Byrsonima 


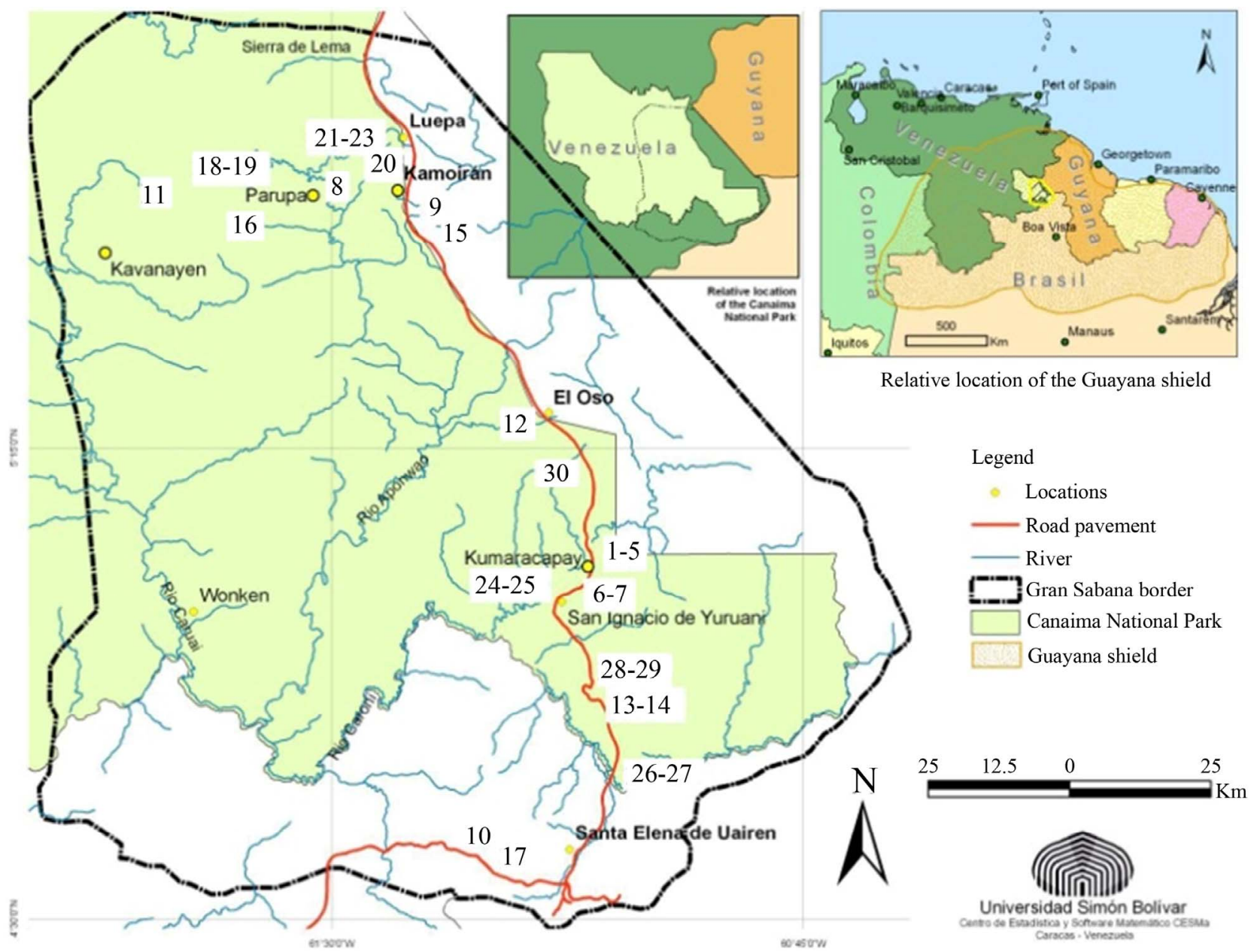

Figure 1. General location of the Gran Sabana and localities studied (1 - 30). “Ariwe Fernland”, “El Oso Forest”, “Quebrada Pacheco Swamp” and “Colonia Fernland” are identified by the numbers 21, 12, 30 and 17 respectively.
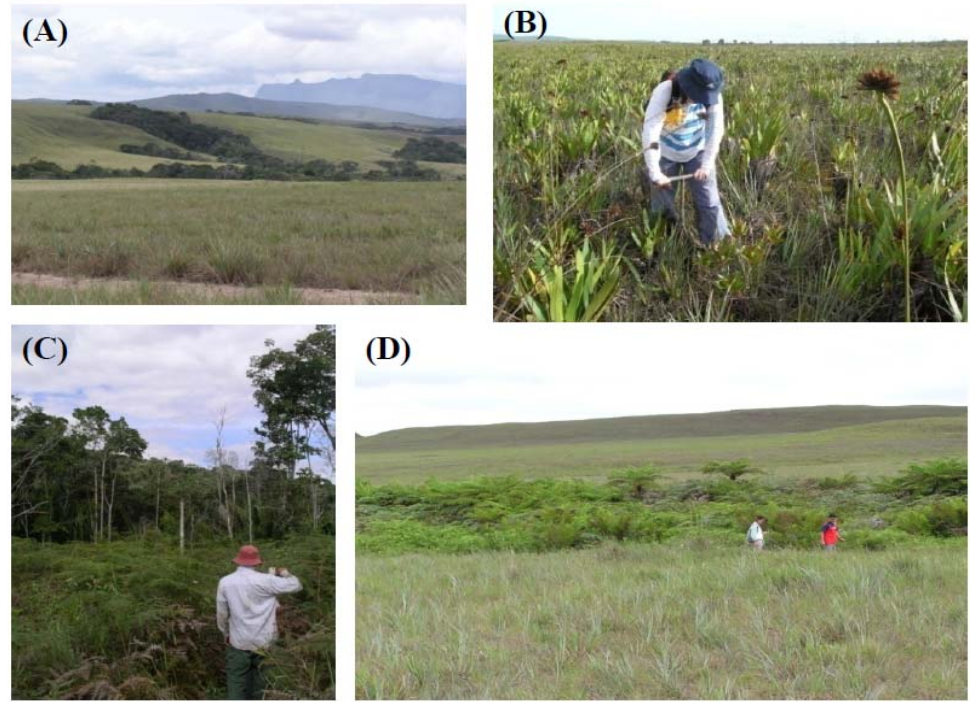

(D)

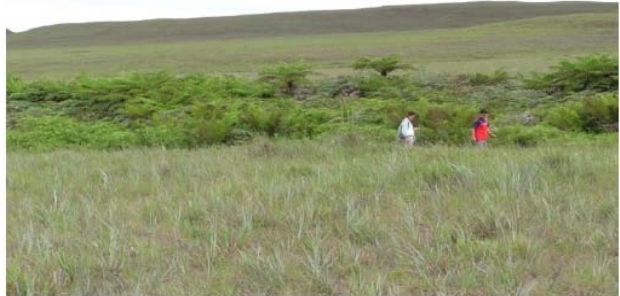

Figure 2. (A) View of the north-eastern sector of the Gran Sabana showing the predominance of treeless savannas, and the patchy distribution of forests; (B) Broadleaved grasslands dominated by Stegolepis ptaritepuiensis; (C) Pteridium aracnoideum fernland forming a belt in a savanna-forest transition; or (D) accompanied by Cyathea sp., as patches in the savanna matrix. 
stipulacea), Sapotaceae (Pouteria bangii), Burseraceae (Protium heptaphyllum), Caryocaraceae (Caryocar montanum), Lecythidaceae (Eschweilera sp.), Araliaceae (Schefflera sp.) and Vochysiaceae (Ruizterania ferruginea, Vochysia sp.) [40,42-44]. The Arecaceae are mainly represented by Euterpe sp. and Geonoma sp. [42-45]. In the matorrales, Vismia (Clusiaceae), Myrcia (Myrtaceae), Miconia (Melastomataceae) and Clethra (Clethraceae) have been identified as the dominant genera [43]. It is important to note the absence of many pioneer genera, which are otherwise very common in the Neotropical lowlands and uplands. For example, Cecropia (Cecropiaceae) is only found in a very few places in the Gran Sabana where apparently more fertile conditions, such as areas with diabase intrusions, are found [41].

\subsubsection{Savannas}

Savannas are dominated by Trachypogon spicatus, Axonpus anceps (Poaceae) and many Cyperaceae species, for example, Bulbostylis paradoxa, Lagenocarpus rigidus and Hypolytrum pulchrum [46-50]. In these savannas Poaceae and Cyperaceae are co-dominant, with Cyperaceae accounting for c.a. $50 \%$ of the total above-ground biomass [38].

Another particular characteristic of these savannas is that they lack several typical tree species normally found in Neotropical savannas, such as Curatella americana and Byrsonima crassifolia $[38,45,51]$. The first of these is totally absent in the uplands and the second is only seen in a few places to the south [47] and northwest. The Gran Sabana savannas are, in fact, treeless, and only dwarf shrubs of Byrsonima verbascifolia may be observed. Other ligneous dicots belonging to the Melas-tomataceae, Asteraceae, Clusiaceae and Rubiaceae are almost completely restricted to savanna-forest borders or grow on termites' nests in savannas close to forested areas [50]. Arboreal and herbaceous legumes are also totally absent from these savannas [38,51].

\subsubsection{Savanna-Forest Borders}

According to references [34,43,52], a gradual transition of woody communities from savannas to tall forests can sometimes be observed: from savannas to matorrales, matorrales to secondary forests, and secondary forests to tall forests. In the Gran Sabana, stands of Vismia, Myrcia, Miconia and Baccharis (Asteraceae) are followed by secondary forests with Clusia, Myrsine and Humiria, and then tall forests dominated by Dimorphandra macrostachya, Euterpe, Tachigali and Eucearea. Other savanna-forest borders are characterized by the presence of Microlicia (Melastomataceae), Miconia, Vismia and Clusia or by Pteridum aracnoideum fernlands, which are more or less represented by woody elements and young trees [50].

\subsubsection{Other Communities}

Many other communities are also present in the region including broadleaved grasslands (so called "herbazales") unique to the Guayana Shield (Figure 2(B)) dominated by Stegolepis ptaritepuiensis (Rapateaceae) [46,47,53]. In the floodplains and riversides to the south below 1.000 m masl, palm swamps dominated by Mauritia flexuosa (Arecaceae) together with Poaceae, Cyperaceae and a variable woody component are also present [47]. Fernlands dominated by Pteridium aracnoideum are also found as transitional belts along savanna-forest boundaries (Figure 2(C)) or, accompanied by Cyathea sp., in topographic depressions (Figure 2(D)) forming patches in the treeless savanna. The shrublands of the Guayana uplands are also a particular and well defined type of vegetation, growing mainly in sandstone outcrops, white sands, or less frequently, peat bogs [47].

\section{Methods}

\subsection{Sampling and Laboratory Procedures}

Surface soil samples for pollen rain characterization were recovered from 30 sites (see Figure 1 for relative locations). These included gallery and montane forests, fallows, savanna-forest borders, swamps, mires and fernlands. The main features of the selected communities are summarized in Table 1.

Four of the localities along savanna-forest borders or rivers were selected for the study of past vegetation dynamics: "Ariwe Fernland", "El Oso Forest", "Quebrada Pacheco Swamp" and "Colonia Fernland" (Figure 1). Three of these communities where located on well-drained soils, while Quebrada Pacheco Swamp was located in a flooded valley. The principal characteristics of these study sites are summarized in Table 2.

Samples for modern pollen rain characterization were taken from the first $2 \mathrm{~cm}$ of surface soil. Each sample was composed of 5 sub-samples taken in a $1 / 2$ ha plot, in order to ensure representativity (following [11]). Sedimentation rates obtained by $[7,8]$ indicate that these $2 \mathrm{~cm}$ probably represent the last c.a. 50 years of pollen accumulation.

In Ariwe Fernland and Quebrada Pacheco, cores of 194 and $200 \mathrm{~cm}$, respectively, were taken with a Dachnowski corer, while in El Oso Forest and Colonia Fernland soil profiles $1 \mathrm{~m}$ deep were manually excavated just within the forest border, and samples were taken at 10 cm intervals.

An aliquot of $2 \mathrm{~cm}^{3}$ for every soil or sediment sample was taken for pollen analysis and standard methods of acetolysis and the removal of silicates and humic acids were used for sample preparation [54-56]. Lycopodium tablets were added before preparation to estimate the 
Guayana and Its Use in Vegetation Reconstructions from Sedimentary Records

Table 1. Main features of the study sites selected for the pollen rain characterization. Numbers correspond to the localities shown in Figures 1, 3 and 5(a).

\begin{tabular}{|c|c|c|}
\hline & Site (Altitude masl) & Vegetation type \\
\hline 1 & Kumaracapay Forest 1 (950) & Slash \& burn fallow surrounded by tall forests and treeless savannas \\
\hline 2 & Kumaracapay Forest 2 (950) & Slash \& burn fallow surrounded by tall forests and treeless savannas \\
\hline 3 & Kumaracapay Forest 3 (850) & Tall montane forest surrounded by slash \& burn plots and treeless savannas \\
\hline 4 & Kumaracapay Forest 4 (850) & Disturbed forests bordering the main regional highway \\
\hline 5 & Kumaracapay Forest 5 (950) & Tall montane forest surrounded by slash \& burn plots and treeless savannas \\
\hline 6 & San Ignacio Forest 1 (890) & Tall montane forest, not cultivated, surrounded by treeless savannas \\
\hline 7 & San Ignacio Forest 2 (890) & Tall montane forest, not cultivated, surrounded by treeless savannas \\
\hline 8 & Arautaparú Forest (1.260) & Gallery forest patch no more than $500 \mathrm{~m}$ perimeter in a treeless savanna matrix \\
\hline 9 & Kamoirán Forest (1.200) & Gallery forest patch no more than $800 \mathrm{~m}$ perimeter in a treeless savanna matrix \\
\hline 10 & El Pauji Forest (1.080) & Tall montane forest with slash \& burn plots neighboring treeless savannas \\
\hline 11 & Mantopai Forest (1.100) & Gallery forest patch in a treeless savanna matrix \\
\hline 13 & Jaspe Forest (900) & Very thin and open "matorral" along the Jaspe stream \\
\hline 14 & Jaspe Savanna/Forest (900) & Woody forest-savanna transition 2 - 3 m long \\
\hline 15 & Kamoirán Savanna/Forest (1.250) & P. aracnoideum fernland $3.5 \mathrm{~m}$ long in a forest-savanna transition \\
\hline 16 & Chivatón Savanna/Forest (1.200) & P. aracnoideum fernland $5 \mathrm{~m}$ long in a forest-savanna transition \\
\hline 17 & Waramasén Savanna/Forest (1.090) & P. aracnoideum fernland $8 \mathrm{~m}$ long in a forest-savanna transition \\
\hline 18 & Liworiwó Grassland (1.300) & Broadleaved Stegolepis and Brocchinia grassland in a treeless savanna matrix \\
\hline 19 & Liworiwó Fernland (1.300) & P. aracnoideum and Cyathea sp. fernland patch in a treeless savanna matrix \\
\hline 20 & Luepa Fernland (1.350) & P. aracnoideum and Cyathea sp. fernland patch in a treeless savanna matrix \\
\hline 21 & Ariwe Fernland 1 (1.210) & P. aracnoideum and Cyathea sp. fernland patch in a treeless savanna matrix \\
\hline 22 & Ariwe Fernland 2 (1.210) & P. aracnoideum and Cyathea sp. fernland patch in a treeless savanna matrix \\
\hline 23 & Awarkay Fernland (1.200) & P. aracnoideum and Cyathea sp. fernland patch in a treeless savanna matrix \\
\hline 24 & Kumaracapay Swamp 1 (880) & Mauritia swamp with abundant woody component \\
\hline 26 & Kukenán Swamp 1 (900) & Mauritia swamp with a low woody component \\
\hline 27 & Kukenán Swamp 2 (900) & Mauritia swamp with a low woody component \\
\hline 28 & Mapaurí Swamp 1 (950) & Mauritia swamp with a low woody component \\
\hline 29 & Mapaurí Swamp 2 (950) & Mauritia swamp with abundant woody component \\
\hline 30 & Quebrada Pacheco Swamp (1.050) & Mauritia swamp with a low woody component \\
\hline
\end{tabular}

Table 2. Main features of the study sites selected for the sampling of sedimentary records.

\begin{tabular}{|c|c|c|c|c|c|c|c|}
\hline Locality & $\begin{array}{c}\text { Location/Altitude } \\
\text { (masl) }\end{array}$ & $\begin{array}{l}\text { Main parent } \\
\text { material }\end{array}$ & Present vegetation & $\begin{array}{l}\text { Surrounding } \\
\text { vegetation }\end{array}$ & $\begin{array}{c}\text { Location of } \\
\text { sedimentary record }\end{array}$ & Type & Length \\
\hline Ariwe Fernland & $\begin{array}{c}05^{\circ} 43^{\prime} 08^{\prime \prime} \mathrm{N} \\
61^{\circ} 33^{\prime} 28^{\prime \prime} \mathrm{W} / 1.250\end{array}$ & sandstone & $\begin{array}{l}\text { Pteridium aracnoideum } \\
\text { fernland }\end{array}$ & $\begin{array}{l}\text { Treeless savannas with } \\
\text { patches of gallery forests }\end{array}$ & $\begin{array}{l}\text { Riverside, within } \\
\text { fernland }\end{array}$ & Core & $194 \mathrm{~cm}$ \\
\hline El Oso Forest & $\begin{array}{c}05^{\circ} 16^{\prime} 27^{\prime \prime} \mathrm{N} \\
61^{\circ} 07^{\prime} 20^{\prime \prime} \mathrm{W} / 1.259\end{array}$ & sandstone & $\begin{array}{l}\text { Small gallery forest patch } \\
(800 \text { m perimeter }) \\
\text { dominated by } \\
\text { Dimorphandra } \\
\text { macrostachya }\end{array}$ & $\begin{array}{l}\text { Treeless savannas with } \\
\text { patches of gallery forests }\end{array}$ & $\begin{array}{c}\text { Savanna-forest } \\
\text { border }\end{array}$ & Soil profile & $80 \mathrm{~cm}$ \\
\hline $\begin{array}{c}\text { Quebrada } \\
\text { Pacheco Swamp }\end{array}$ & $\begin{array}{c}5^{\circ} 43^{\prime} 49^{\prime \prime} \mathrm{N} \\
61^{\circ} 06^{\prime} 37.5^{\prime \prime} \mathrm{W} / 1.040\end{array}$ & sandstone & Mauritia flexuosa swamp & $\begin{array}{l}\text { Treeless savannas with } \\
\text { patches of gallery forests }\end{array}$ & Within palm swamp & Core & $190 \mathrm{~cm}$ \\
\hline $\begin{array}{l}\text { Colonia } \\
\text { Fernland }\end{array}$ & $\begin{array}{c}4^{\circ} 33^{\prime} 28^{\prime \prime N} \\
61^{\circ} 11^{\prime} 58^{\prime \prime} \mathrm{W} / 1.100\end{array}$ & diabase & $\begin{array}{l}\text { Montane forest dominated } \\
\text { by Protium, Vochysia, } \\
\text { Alchornea, Schefflera, } \\
\text { with many slash \& burn } \\
\text { plots and fallows }\end{array}$ & $\begin{array}{l}\text { Evergreen montane } \\
\text { forests with treeless } \\
\text { savanna patches }\end{array}$ & $\begin{array}{l}\text { Savanna-forest } \\
\text { border, within } \\
\text { Pteridium fernland }\end{array}$ & Soil profile & $90 \mathrm{~cm}$ \\
\hline
\end{tabular}


concentrations of individual pollen types and ecological groups [57].

Palynomorphs were quantified by preparing slides with a glicerin-glicerinated gelatin mixture and then counting them using a light microscope. At least 300 pollen grains from terrestrial taxa were counted for most samples. Pollen was identified to either family or genus level, and spores were classified into types following the pollen \& spores atlases compiled by [58-63].

For AMS radiocarbon dating, samples from cores and soil profiles were selected and sent to the GADAM Centre in Gliwice, Poland. Dates were calibrated with Calib 5.01 (Stuiver \& Reimer 1986-2011, available at: http://calib.qub.ac.uk/calib/).

\subsection{Data Analysis and Presentation}

The pollen data is presented as percentages of the terrestrial pollen sum including all pollen sourced from terrestrial taxa. Ferns, fungi and algae and other azonal taxa (such as aquatic taxa) were considered separately. Pollen from Cyperaceae species was considered within the pollen sum, since this family represents an important component of savanna communities [38]. All the pollen from woody taxa and legumes was considered in the "forest trees, shrubs or liana groups", since even species of Asteraceae, Melastomataceae, Rubiaceae, Euphorbiaceae and Fabaceae families, were strongly restricted to forest communities or ecotones in our study area [50].

The abundance of each individual taxon and that of the ecological groups considered at each site were plotted in pollen diagrams with PSIMPOLL 4.10, PSCOMB 1.04 free software following Bennett (2002), available at: http://chrono.qub.ac.uk/psimpoll/psimpoll.html. For the pollen rain samples, all taxa with percentages higher than $1 \%$ are shown in the pollen diagram. The rest are listed in Table 3. In the case of the sedimentary records, only the sum of the pollen for each of the ecological groups are shown, together with charcoal particles $>100 \mathrm{um}$, and fungi, algae and aquatic plant concentrations.

Principal Component Analysis (PCA) based on the
Euclidean distance was performed with MVSP 3.1 to obtain an ordination of localities with respect to their pollen spectra. The results of these analyses are shown in two Euclidian biplots (Figures 5(a) and (b)).

\section{Results and Interpretation}

\subsection{Modern Pollen Representation in Soils}

A total of 76 terrestrial pollen types, 16 types of fern spores and 4 pollen types from aquatic plants were found in the modern samples analyzed. All the terrestrial pollen is listed in Appendix 1 and the best represented taxa are also included in the pollen diagram (Figure 3). In this diagram, samples were ordered by the increasing percentage of savanna herbs, giving three main pollen groups or assemblages: 1) forests, 2) savanna-forest borders and 3) swamps/fernlands/grasslands. These assemblages are described as below.

\subsubsection{Forests}

Within the forests, $70 \%-90 \%$ of pollen collected was from forest trees, shrubs and lianas (Figure 3). Pollen from savanna herbs came to between $10 \%-30 \%$, with Poaceae as the best represented family. Indeed while pollen from members of the Cyperaceae exhibited values of between $0 \%-5 \%$ in forest samples, pollen from the Poaceae was generally around $1 \%$ - 25\% (Figure 4). In addition, the percentages of pollen from both these families: Poaceae and Cyperaceae were higher in gallery forests and fallows than in closed montane forests (Figures 3 and 4$)$.

As regards pollen composition, the pollen types best represented from woody elements were: Dimorphandra, Pourouma, Pouteria/Chrysophyllum, Protium, Schefflera, Ilex, Asteraceae, Miconia and Blepharandra (Figure 3). Pollen from other genera, for example, Clusia, Pouteria, Euceraea, Qualea, Mabea, and genera not shown in Figure 3 but recorded in Table 3, such as Caryocar, Caraipa, Cordia, Euplassa, Tachigali, Tapura and Vochysia were only recorded at very low abundances.

Table 3. Radiocarbon dates and calibrated dates in bulk samples for the soil profiles studied. $\mathrm{AF}=\mathrm{Ariwe}$ Fernland, $\mathrm{OF}=\mathrm{El}$ Oso Forest, QPS = Quebrada Pacheco Swamp, and CF = Colonia Fernland.

\begin{tabular}{ccccc}
\hline Sample-depth $(\mathbf{c m})$ & Present vegetation & ${ }^{14} \mathbf{C}$ date & Cal. age (yr BP) & Laboratory N $^{\circ}$ \\
\hline AF-46 & Fernland & $850(+/-40)$ & $683-802$ & GdA-1671 \\
AF-120 & Fernland & $2.080(+/-25)$ & $2.040-2.176$ & GdA-1662 \\
OF1-40 & Savanna-forest border & $200(+/-25)$ & $145-190$ & GdA-2066 \\
QPS-90 & Mauritia swamp & $605(+/-25)$ & $576-652$ & GdA-1663 \\
QPS-259 & Mauritia swamp & $1.250(+/-60)$ & $1.056-1.293$ & GdA-1668 \\
HC-35 & Savanna-forest border & $515(+/-25)$ & $507-554$ & GdA-2063 \\
HC-91 & Savanna-forest border & $1.535(+/-25)$ & $1.356-1.448$ & GdA-2065 \\
\hline
\end{tabular}


A Contribution to Pollen Rain Characterization in Forest-Savanna Mosaics of the Venezuelan

Guayana and Its Use in Vegetation Reconstructions from Sedimentary Records

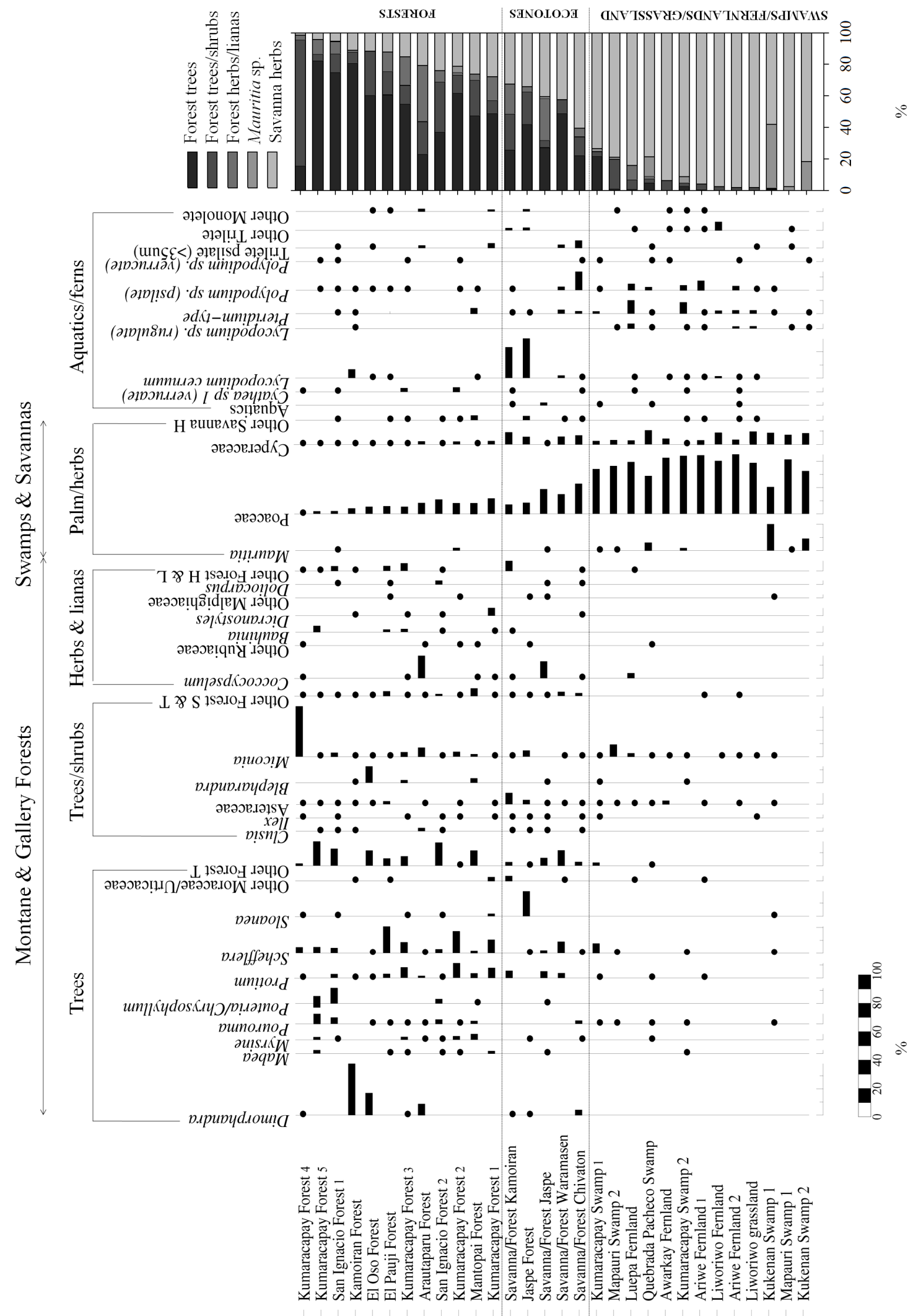

Figure 3. Pollen diagram of surface soil samples. The pollen sum for each ecological group is also shown. Dots represent values less than $5 \%$. 

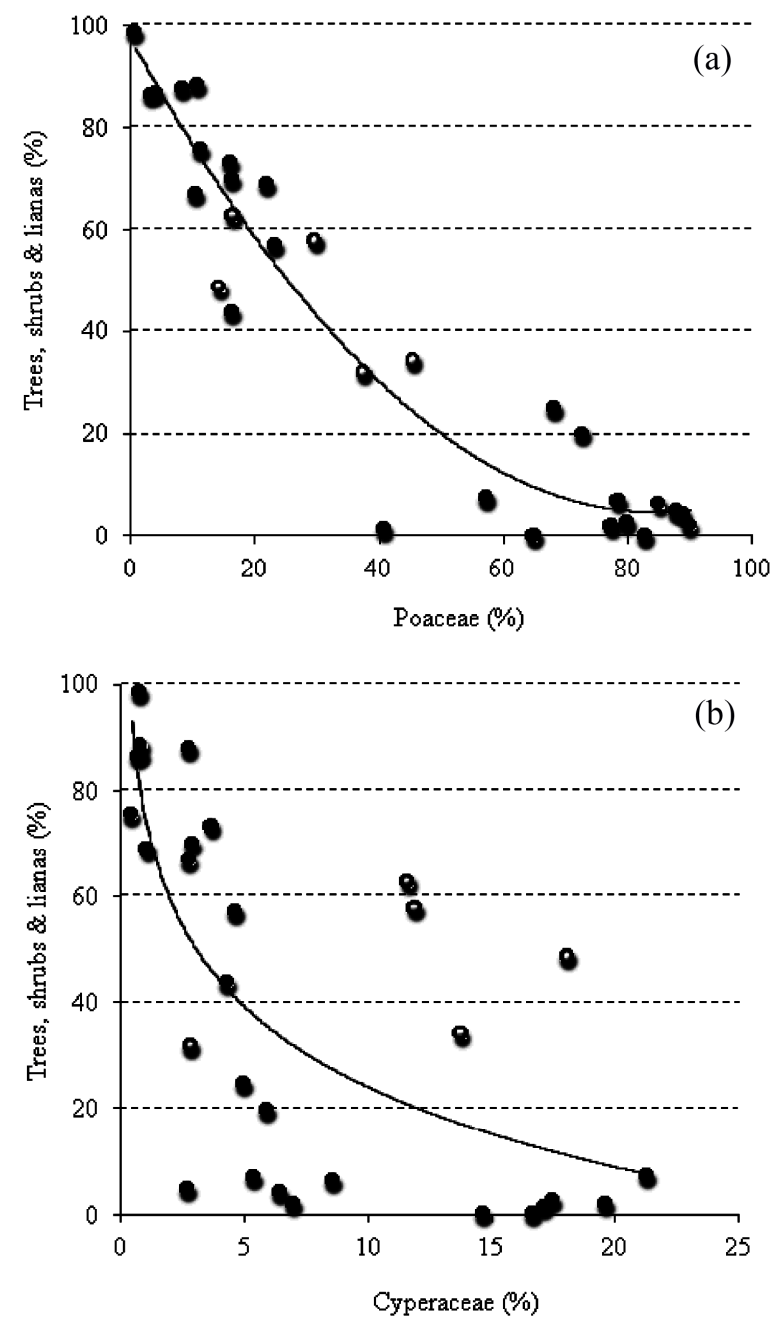

- Forest $\bullet$ Forest-savanna borders $\bullet$ Swamps, fernlands, grasslands

Figure 4. Relationship between Poaceae (a) and Cyperaceae (b) pollen percentages and the representation of forest trees, shrubs and lianas in the $\mathbf{3 0}$ localities studied.

We expected to find pollen grains from cultivated plants in some of the soils studied, especially in the $\mathrm{Ku}-$ maracapay fallow forests; sites 1 and 2 (Appendix 1). At these sites, Manihot esculenta (cassava) and Zea mays (corn) were cultivated only a few years ago, however, pollen from these cultigens was absent in surface soils. Pollen types from the Lauraceae were also absent in spite of the fact that this has been identified as a dominant family in Guayanese forests $[40,42,44]$.

It is important to note that despite the high similarity exhibited in the pollen rain collected from different forest soils, some pollen types, such as Dimorphandra and Schefflera showed different abundances in different sectors of the Gran Sabana. Thus, Dimorphandra pollen was abundant in some gallery forests in the northern and central sectors, but was almost absent from forests in the south, for example, Kumaracapay, San Ignacio and El Pauji (Figure 3). Conversely, Schefflera-type pollen was abundant in forests in the southern Gran Sabana, but rare in gallery forests to the north (Figure 3).

\subsubsection{Savanna-Forest Borders}

Forest-savanna transitional communities were characterized by gallery forest trees, shrubs and lianas contributing $40 \%-60 \%$ of the pollen sum with $20 \%-50 \%$ coming from the Poaceae (Figures 3 and 4(a)). Total ferns, mainly Lycopodium cernuum, Pteridium and Polypodium were better represented in bordering areas than in closed forest (Figure 3). The distribution of Cyperaceae pollen was similar and around $10 \%$ in most savanna-forest border samples (Figures 3 and $\mathbf{4 ( b )}$ ).

The main pollen types from woody plants were Sloanea, Schefflera, Protium and Asteraceae. This last was also better represented along borders than in closed forests (Figure 3). It is noteworthy that Clusia spp. were poorly represented in ecotone samples (Figure 3), since this genus is considered an important component of forest edges [50].

\subsubsection{Swamps/Fernlands/Grasslands}

In general terms, swamps, fernlands and grasslands showed very similar pollen assemblages, with a very high abundance, above $70 \%$, of savanna herb pollen types, and a scarce woody component, generally below $5 \%$ and never higher than 20\% (Figure 3). Since woody elements were not well represented in these samples, pollen-type richness tended to be low (Figure 3); the Poaceae alone generally accounting for more than $40 \%$ of the pollen sum (Figures 3 and 4(a)). Mauritia pollen was only present in palm swamps, as expected. Stegolepis pollen was not plotted in the summary diagram (Figure 3) since it was only recorded from the Liworiwo grassland at very low abundances (lower than 1\%).

Fern spores were not significantly more abundant in fernlands compared to the other communities studied and showed similar abundances in all the open herbaceous communities (Figure 3). Only Pteridium-type pollen was more abundant in Pteridium fernlands than in the other communities (Figure 3).

Aquatics were only represented by a few grains of Eriocaulon, Ludwigia, Drosera and Sagittaria (data not shown) and were recorded from a couple of palm swamps and one fernland, as can be seen from the sum of aquatic pollen types presented in Figure 3.

Although Poaceae pollen was considerably higher in swamps, fernlands and grasslands than in any other community studied (Figure 4(a)) the abundance of Cyperaceae pollen varied between communities (Figure 4(b)); from as low as $2 \%$ to as high as $22 \%$. 


\subsection{Ordination of Surface Samples}

The ordination of the surface soil samples using Principal Component Analysis is shown in Figure 5(a). The first component accounted for $54 \%$ of the variability and the second one, $15 \%$. Samples were ordered in a gradientlike way along the first component, from left to right, with forests located to the left hand side of the plot, savanna-forest borders in the center close to some fallow

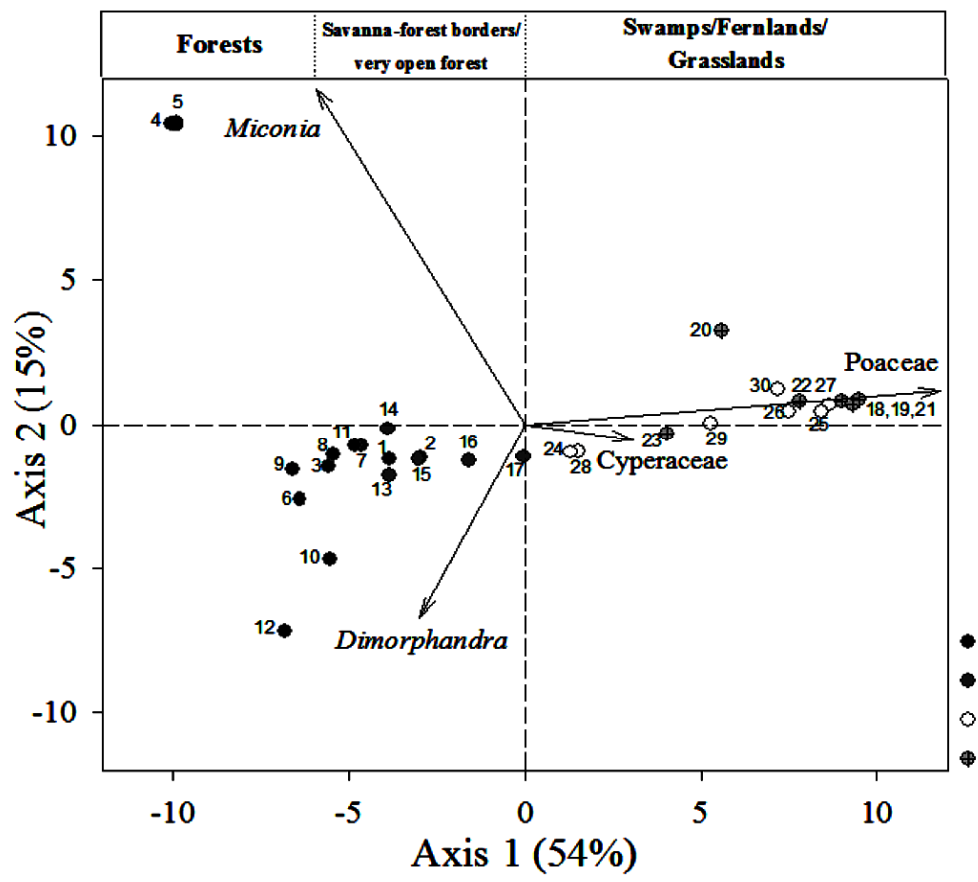

(a)

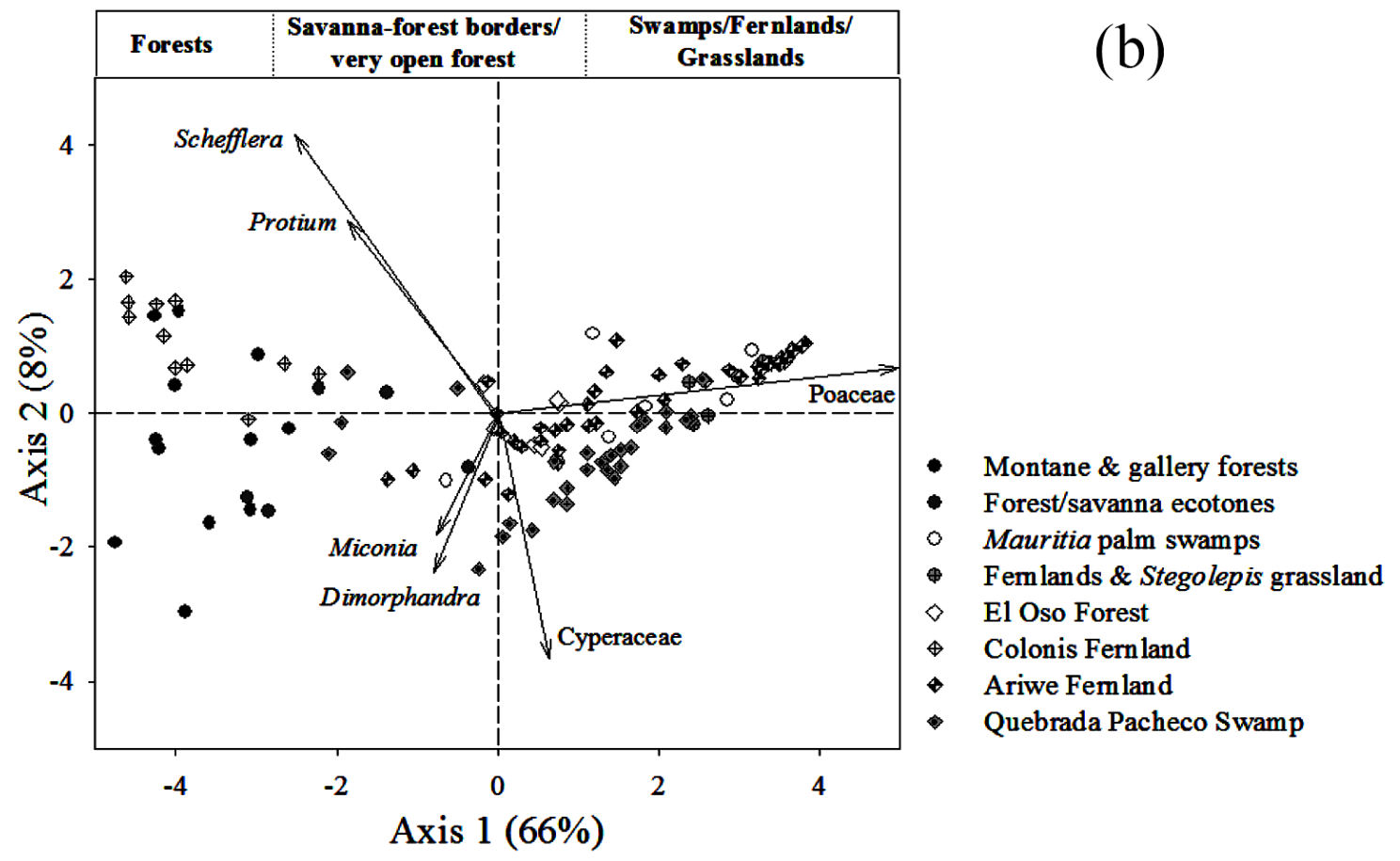

Figure 5. (a) Principal Component Analysis (PCA) of pollen rain samples based on 76 terrestrial pollen types. Vectors of variables with the highest contributions to each ordination axis are shown. Numbers correspond to localities summarized in Table 1. (b) PCA showing the ordination of samples from sedimentary records together with pollen rain samples. The analysis was based on 97 samples and 114 taxa. Vectors of variables with the highest contribution to each ordination axis are also shown. 
samples, and herbaceous communities located to the right (Figure 5(a)). Every point in Figure 5(a) can be identified by revising the localities listed in Table 1.

The main variables contributing to the ordination of the first component were Poaceae and Cyperaceae. Hence, the PCA is reproducing what can be observed from Figure 3, namely, that it is clear that samples can be ordered as a function of the contribution of savanna herb vs. arboreal pollen. This is then, a gradient related to the degree of openness of the vegetation from where the samples were taken.

On the other hand, the two variables with most weight in the vertical ordination (second component) were $\mathrm{Di}$ morphandra and Miconia. This second component apparently shows the floristic differences between forest assemblages, with samples from Kumnaracapay forest, sites 4 and 5 , on the upper left hand side, and the rest of the forest samples more or less clustered around the center left. Kumnaracapay forest sites 4 and 5 are probably separated due to the high abundance of Miconia recorded in them and the absence and/or very low frequency of Dimorphandra (Figure 3).

Savanna-forest border samples were highly correlated, both with each other and with the fallow samples (Figure 5(a), Table 1), suggesting similar pollen assemblages between these two community types.

Finally, swamps, fernlands and grasslands clustered together on the right hand side of the plot (Figure 5(a)), as a function of Poaceae pollen abundance (increasing from left to right).

\subsection{Vegetation Changes Recorded in the Soil Profiles}

A detailed description of sedimentary records was not a main objective of this contribution; we only wish to illustrate how modern pollen rain data could be helpful for describing past vegetation changes. With this in mind, the vegetation changes observed at the four sites considered here, Ariwe Fernland, El Oso Forest, Quebrada Pacheco Swamp and Colonia Fernland, are concisely described in Appendix 2. Additionally, summary diagrams giving the time series for each ecological group at each of the four sites are shown in Figures 6-9. Radiocarbon dates for the four records considered are listed in Table 3.

From Appendix 2, Table 3, and Figures 6-9, it can be observed that pollen assemblages showed considerable changes along the depth/age axis in Ariwe Fernland and Quebrada Pacheco Swamp, but remained more stable in Colonia Fernland and virtually unchanged in El Oso Forest. In Ariwe Fernland and Quebrada Pacheco Swamp, forest types were more frequent at the beginning of the record (around 3.400 and $1.000 \mathrm{yr} \mathrm{BP}$, respectively) than in the top samples, suggesting that vegetation changes have occurred at both these sites (Appendix 2, Figures 6 and 7). In contrast, in El Oso Forest, the pollen assemblages seem to have been quite stable, suggesting that

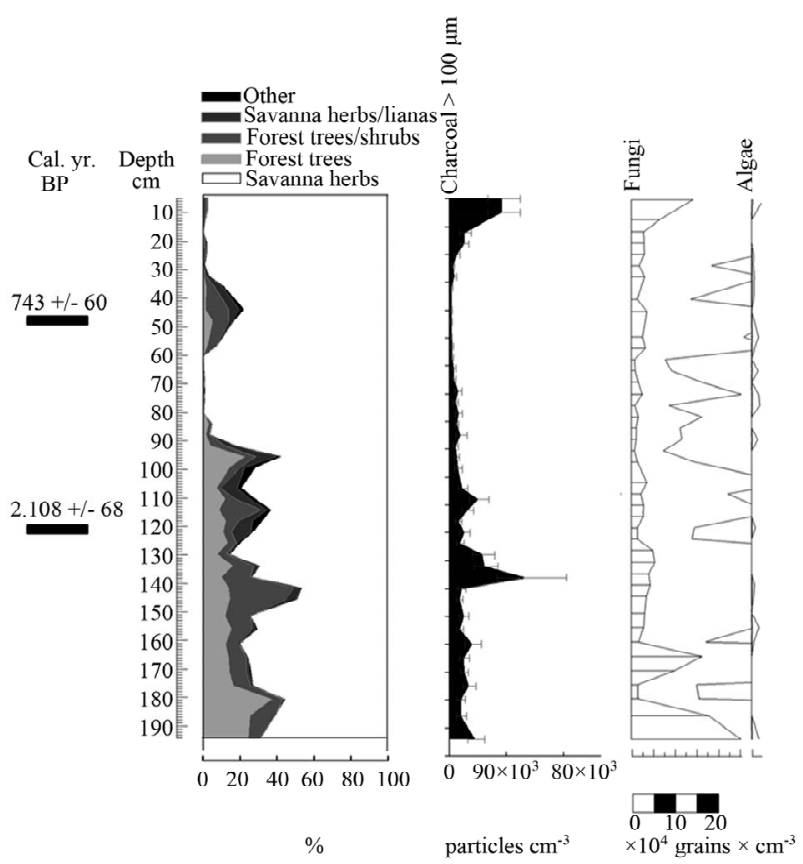

Figure 6. Summary diagrams of ecological groups for Ariwe Fernland. Charcoal, fungi and algae concentrations are also shown.

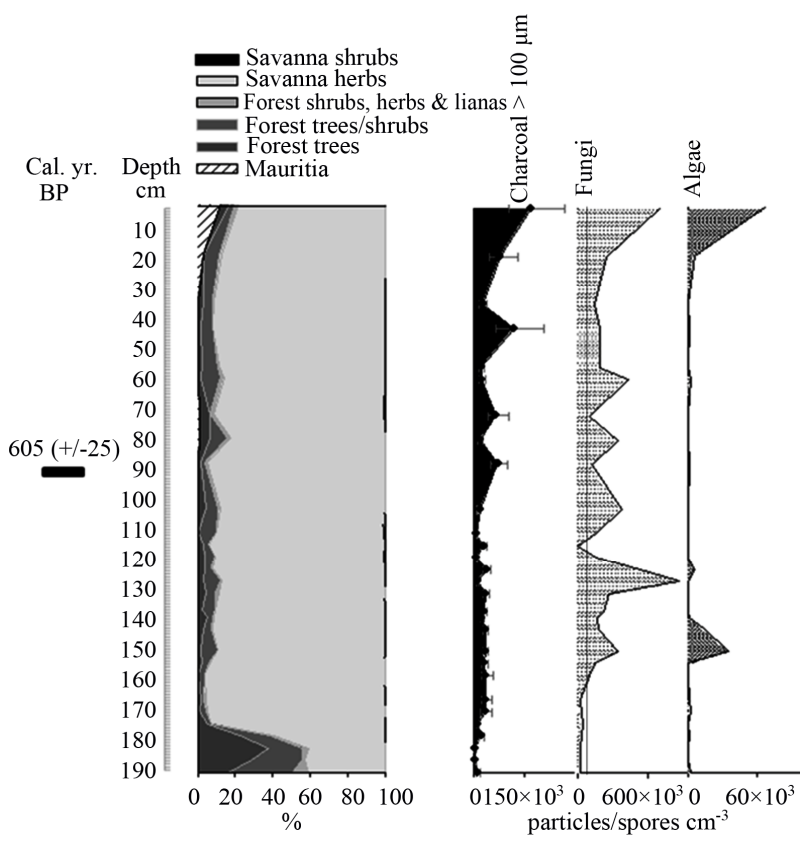

Figure 7. Summary diagrams of ecological groups for Quebrada Pacheco Swamp. Charcoal, fungi and algae concentrations are also shown. 


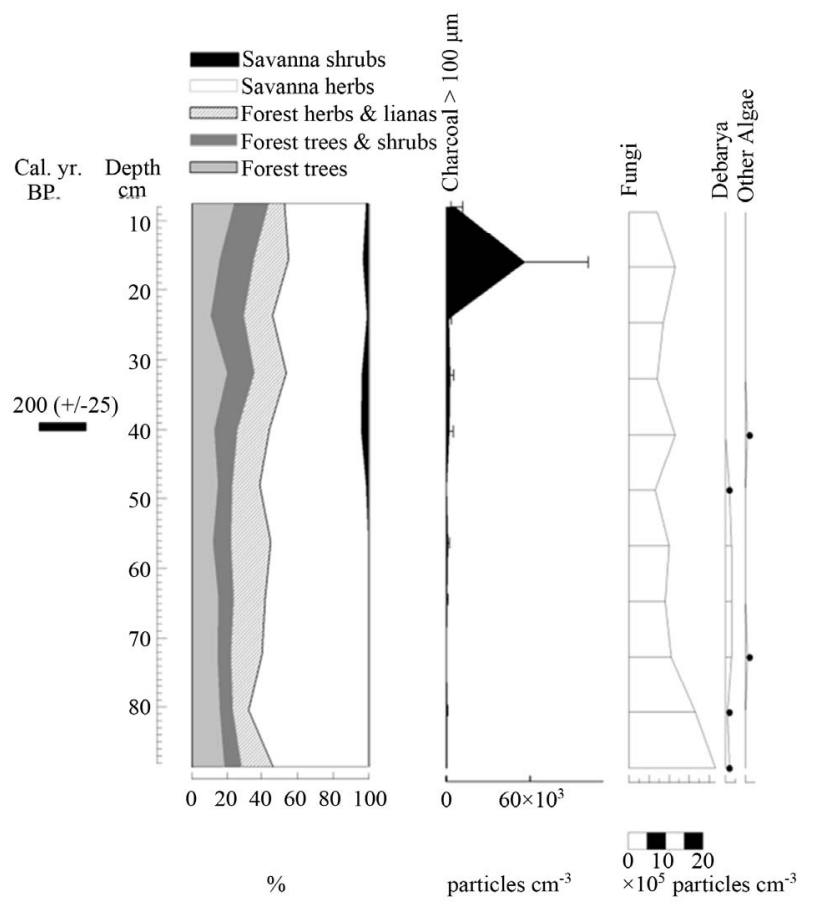

Figure 8. Summary diagrams of ecological groups for El Oso Forest. Charcoal, fungi and algae concentrations are also shown.

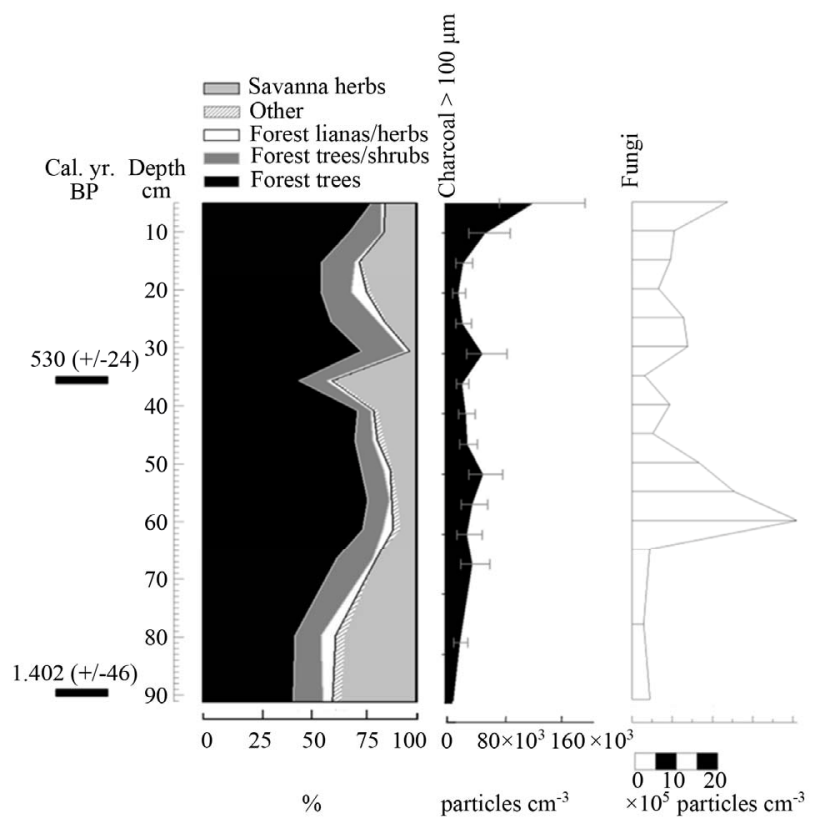

Figure 9. Summary diagrams of ecological groups for Colonia Fernland. Charcoal, fungi and algae concentrations are also shown.

there have been no vegetation changes in the last $500 \mathrm{yr}$. BP (Appendix 2, Figure 8). In Colonia Fernland the proportion of forest to savanna types was significantly different at the bottom of the core (around $1.400 \mathrm{yr}$. BP) to that registered in recent times, suggesting that the structure of vegetation has also changed over time at this site (Appendix 2, Figure 9).

To know what types of communities could be inferred by the pollen assemblages in the four cores studied, the samples from the sedimentary records were ordered together with the surface soil samples of Figure 5(a). The resulting PCA analysis is shown in Figure 5(b). In this analysis $80 \%$ of data variance was accounted for by the first two components. It can be observed that the samples from the sedimentary records were also ordered from left to right, in a similar way to that of the surface soil samples in Figure 5(a). Thus, samples from Ariwe Fernland and Quebrada Pacheco Swamp were distributed from the center to the right hand side (from bordering areas \& forest fallows to the savanna), while samples from the El Oso Forest record were located in the center right (on the forest-savanna border side). Conversely, samples from Colonia Fernland were grouped towards the extreme left (tall forest side) and some of them slightly to the center (savanna-forest border side).

None of the samples that came from soil profiles and cores were ordered differently to the modern samples, suggesting that surface samples contain pollen assemblages similar to those found in the sedimentary records (Figure 5(b)). This makes correlations between present and former pollen assemblages likely, allowing us to interpret the occurrence of a variety of past plant associations along the gradient from closed to open communities, as is explained below.

\subsubsection{Ariwe Fernland}

From the ordination shown in Figure 5(b), it can be seen that soil samples from the base of the core taken from Ariwe Fernland correlate with modern samples taken from savanna-forest borders. Currently, the River Ariwe bank, from where the core was taken, is covered by treeless savannas and fernlands (Table 2). However, paleoecological data indicates the presence of a woody community that might have developed in the study area from 3.400 to 1.200 yr BP (Figure 6). This community was apparently a gallery forest dominated by Dimorphandra (Appendix 2) and was probably similar to current gallery forests in Arautaparú or Kamoirán (Table 1). However, given the low proportion of forest tree and shrub pollen recorded (less than $40 \%$ of the pollen sum (Figure 6), it can be inferred that this gallery forest was very open, possibly indicating a high degree of disturbance. The high similarity of the pollen from the base of the core samples of this sedimentary record with the pollen collected from modern savanna-forest border samples, suggests that structurally, the former community could have been similar to a current "matorral". As coarse charcoal 
particles were abundant at these levels, the recurrent incidence of local fires can be also inferred, suggesting that fire could have been an important disturbance factor (Figure 6).

Conversely, samples from the last $1.000 \mathrm{yr}$ BP to the present were ordered on the right hand side, some of them to the extreme right, very close to samples from herbaceous communities. This could indicate the development of a very open community, similar to that found today in the study area (Table 2). Thus, a replacement of vegetation occurred in Ariwe Fernland, from a woody community similar to a savanna-forest border or "matorral", to a predominantly herbaceous community. It is probable that fire caused this vegetation substitution.

\subsubsection{El Oso Forest}

In contrast to Ariwe Fernland, samples from El Oso Forest are grouped together in the central-right sector of the PCA (Figure 5(a)), close to samples taken from savanna-forest borders. This suggests that the current character of a forest-savanna transition has remained unchanged over the last $500 \mathrm{yr}$ (Figure 7). Abundance patterns in the core seem to have also remained stable, with Dimorphandra being the dominant genus, as is observed today. Charcoal particles are almost absent, indicating that there have been no local fires in the study area in the last few centuries.

\subsubsection{Quebrada Pacheco Swamp}

The ordination of samples from Quebrada Pacheco Swamp, from the center to the right of the PCA, shows a similar pattern to that of the Ariwe Fernland samples, suggesting that a vegetation substitution also occurred at this site (Figure 8). Comparing the pollen assemblages from the base of the Quebrada Pacheco core with modern soil samples, a clear correlation with samples from open forests and savanna-forest borders can be observed. It can be inferred therefore, that a woody community (probably a very open gallery forest) existed at this site around $1.000 \mathrm{yr}$ BP. With a tree and shrub pollen sum of around $60 \%$, this assemblage looks very similar to current savanna-forest borders (compare Figures 3 and 6). Again, the development of a very open disturbed forest or a "matorral" can be inferred from the pollen at the base of the Quebrada Pacheco core.

Mauritia was absent in the study site until the last 3 or 4 centuries. This palm has colonized this area recently, with the establishment of an open Mauritia swamp. Based on the similarity of the pollen samples from the top of the Quebrada Pacheco core with modern swamp samples, it seems that a community with characteristics similar to the swamps listed in Table $\mathbf{1}$ developed in the study area.

\subsubsection{Colonia Fernland}

The clustering of most samples from Colonia Fernland at the extreme left of the PCA reveals that these samples are all similar to modern samples taken from tall forests (Figure 5(b)). The ordination of samples in the upper part of the biplot is given by the absence of Dimorphandra pollen and the high abundances of Protium and Schefflera recorded from this core (Appendix 2). These latter species are the main variables influencing the vertical ordination in the analysis. As can be seen from Figure 9, the ecological groups found at Colonia Fernland have experimented only slight changes. In fact, some of the samples from this record were ordered somewhat apart, near the center-left of the PCA. These are samples from the base of the core, which are similar to some of the modern samples from open forests. This suggests that from around 1.200 to $900 \mathrm{yr}$ BP herbs were more abundant than today at this study site, and hence the forest was smaller or its canopy was more open. Thus, in Colonia Fernland the tall forests seem to have expanded or increased in density (Figure 9). It is important to highlight that this apparent expansion of the forest and/or the increase in forest canopy density at this site, occurred simultaneously with an increase in charcoal particles. Thus, it seems that the forest at Colonia Fernland has become larger and closer over the last $1.400 \mathrm{yr}$, despite the seeming increase in local fire events.

\section{Discussion}

\subsection{Pollen Abundances in Modern Samples and Their Relationship with the Composition and Structure of Living Plant Communities}

Since this investigation did not include vegetation surveys, the conclusions we could draw about the correlations of pollen types in soils with the current composition of standing communities were limited. Nevertheless, we were able to compare our pollen rain data with available studies on vegetation composition and dominance patterns for plant communities in the Gran Sabana and surrounding areas. Based on this comparison we can conclude that the pollen rain data from forest soils seems to fit very well with forest composition documented in the literature. Many of the pollen types that we expected to find have been actually recorded, such as for example Dimorphandra, Protium, Pourouma, Pouteria and Euceraea, among others. However, not all the important families/genera seem to be well represented in the pollen rain and we suspect that some important genera could be underrepresented, such as for example, the Chrisobalanaceae genera Hirtella and Parinari, as well as Vochysia, Ruizterania, Pouteria and Symphonia. Likewise, Euceraea and Clusia have been listed as dominant genera 
$[40,42,43,50]$, but only a small number of pollen grains were recovered from a few forest soil samples (Figure 3). Under-representation of tropical forest species is common, since there are many entomophilous species whose pollen has a limited spatial dispersal capacity $[14,21,64]$. Nevertheless, in order to test for the under/over-representation of taxa in forest samples it is necessary to carry out vegetation studies at the same sites where the pollen rain is collected, as has been done by other authors (for example $[14,16,17,28])$.

In addition, it seems that there were many silent taxa in the forest samples studied, such as for example members of the Lauraceae (Figure 3, Table 2). It is well known that the pollen grains of this family are very thin-walled and fragile, and sensitive to acetolysis treatment. Thus, it is highly unlikely that pollen grains belonging to this family would be fossilized and preserved in sedimentary records, and those few that were would be dissolved during acetolysis, which is part of the standard procedure for the preparation of pollen slides [65]. The impossibility of recovering pollen from the Lauraceae is a serious obstacle for the study of the history of the forests of the Guayana uplands, since it has been identified as the most structurally important family [44].

Other important taxa that were silent in the pollen record were the cultivated plants. Hence, although two of the forest sites were constituted by fallows (Kumaracapay forest 1 and 2), where Manihot esculenta (cassava) and Zea mayz were cultivated some years ago, no pollen grains of these species were found. The absence of cassava pollen grains could be explained by their very large size and the fact that most plants are harvested before flowering. The absence of Manihot esculenta pollen in soils were it is known that the plants were cultivated some years before should thus be noted, as it reinforces the suggestion that this pollen type is not easily found in sediments outside the immediate archaeological context.

Regarding savanna-forest borders, the composition of pollen types matched very well with the composition reported in the literature. For example, the relatively high abundances of Poaceae and Cyperaceae pollen (Figure 3) might be related not only to the probable transport of these pollen types from neighboring savannas but also with the variety of species in these families specifically associated with forest borders, for example, Scleria brasiliensis from the Cyperaceae, and Imperata basiliensis and Schizachyrium condensatum from the Poaceae [50]. Also some Poaceae and Cyperaceae which are dominant in the surrounding savannas are also found along savanna-forest borders, for example Echinolaena inflexa and Axonopus anceps, as was shown by [50] in a study of the vegetation composition of this ecotone. Asteraceae spe- cies are also found more frequently along borders than in tall forests. For example, Baccharis has been identified as a genus commonly observed in open communities such as "matorrales" [43]. The higher representation of fern spores, particularly Lycopodium and Pteridium, along borders, seems to be related to the higher density of these genera in these areas with respect to their abundance in closed forests [50].

Some pollen types, however, seem to be underrepresented in the pollen rain from savanna-forest borders, for example Clusia. The three Clusia species most often found in ecotones: Clusia grandifloria, C. pusilla and C. schomburgkiana, are some of the most common tree species growing along savanna-forest borders. Again, the probable under-representation of Clusia should be tested in the future coupled with pollen rain-living vegetation studies.

Pollen composition in the Mauritia swamps and grasslands studied was also similar to the composition of living plant communities reported in the literature. Palm swamps were dominated by Mauritia, Poaceae and Cyperaceae pollen, and grasslands by Poaceae, Cyperaceae and the marginal occurrence of Stegolepis pollen (Figure 3). Of course, the impossibility of achieving a higher taxonomic resolution in the identification of Poaceae and Cyperaceae species is an important limitation of the palynological characterization of these communities. In this regard, an attempt to look for pollen size differences between aquatic Poaceae growing in swamps and mires, and Poaceae species growing in well drained savanna soils, could help us to identify the contribution of each species type in pollen assemblages of grass-dominated environments. This has been attempted for a variety of grass-dominated communities in South America, with promising preliminary results [66]. Nevertheless, this approach needs to be tested in other types of grass-dominated environments of tropical South America where the impossibility of discriminating between tribes, genera or species within the very generalist family Poaceae, is the most noteworthy obstacle to our long-term understanding of savanna dynamics.

Regarding the abundance of Mauritia pollen in palm swamps, this was highly variable between sites (Figure 3). This variation may be related to changes in the density of Mauritia stands, as has been suggested in earlier contributions [19] and [67,68]. The representation of woody elements also seems to be reasonably well correlated with woody species actually recorded from palm swamps [69].

In fernlands, the main pollen types were again Poaceae and Cyperaceae, which agrees with the composition of standing communities (Figure 3). Observation of authors 
support that Cyperaceae from neighboring savannas are also commonly found growing together with Pteridium and Cyathea ferns. The same can be said of some Poaceae species, which actually grow better (i.e. individuals are taller and more leafy) in fernlands than in savannas, such as for example Echinolaena inflexa. But the most important components of fernlands: ferns, were not always well represented in the pollen rain. Fern spores were not actually more abundant in fernland soils than in other soils (Figure 3), except for Pteridium spore abundance which seemed to be somewhat related to the abundance of ferns in living plant communities.

\subsection{Source of Pollen, Community Structure and the Interpretation of Poaceae and Cyperaceae Pollen Abundances}

As expected, all the pollen rain samples studied seem to reflect the local income of pollen from plants growing directly in the study area. The representation of extra-local and regional pollen is probably very low, even in the swamp sediments, as suggested by [9] and certainly, the pollen rain of forests, fallows and savanna-forest borders was very local. However, given the mosaic-like character of the study site, and the differences in pollen production/dispersal between savannas and forests, we expected a higher representation of savanna herbs in the pollen rain of woody communities especially as many of the communities studied were represented by relatively low and open forests, or even by very small patches of woodland surrounded by treeless savannas (see Table 1). Thus, in spite of the fact that the Poaceae are known to be prolific producers of wind-dispersed pollen, and considering that many Poaceae species also grow in forest understories (see [70]), the data suggest that relatively low amounts of Poaceae pollen from savannas are penetrating and being deposited on forest soils. It seems then, that the forest cover is acting as a barrier preventing the entry of Poaceae pollen. This conclusion agrees with [71], who suggested that Poaceae was not overrepresented in small catchment basins of the Llanos Orientales in Colombia. The same conclusion was reached by [27] and [30], and earlier suggested by [70], who considered that Poaceae over-representation in the Neotropics mostly occurs in large lakes due to the input of pollen from aquatic grasses.

\subsection{Pollen-Based Discrimination of Plant Communities}

Based on the results discussed above and as shown in Figures 3, 4 and 5(a), we were able to make palynological distinctions between the major vegetation types included in this contribution. In spite of the mosaic-like pattern of the vegetation types in the study area, open communities were easily differentiated from predominantly woody communities from their pollen spectra. Poaceae pollen was identified as the main indicator of vegetation openness. Furthermore, because Poaceae and Cyperaceae pollen was not overrepresented in forest soils, the gradient of openness that exists in the living communities, from closed tall forests to secondary open forests, fallows and bordering areas, was also observed in the pollen assemblages in the soils. This gradient of openness is useful for the identification of forest structure, as it provides an extra dimension with which to interpret palynological data. Similar gradients of openness in pollen rain have been identified by [9] for the southern Gran Sabana, and by $[27,30]$ for rainforest-dry forest-cerrados communities in Amazonia.

Since a gradient was found, the discrete separation of communities seems unlikely in many cases (see Figure 5(a)). Thus, Cyperaceae pollen was not as high in fallows as along savanna-forest borders (Figure 3) and some open gallery forests, such as Arautaparú, showed a high proportion of Cyperaceae species comparable to that found in fallows (Figures 3 and 4). Hence, neither Cyperaceae nor Poaceae can be considered reliable indicators of a fallow occurrence. Of course, the best indicator of a fallow occurrence would be the presence of pollen from cultivated plants; however, neither of the soil samples taken from fallow forests yielded pollen from these types of plants (Figure 3, Table 2).

Regarding the transition areas, we found that Poaceae and Cyperaceae pollen as well as fern spores and Asteraceae pollen were all significantly higher in ecotones than in closed forests, (Figures 3 and 4). Thus, they could be used as reliable indicators for palynological differentiation between closed forests and transitional communities.

Palm swamps, fernlands and grasslands showed very similar pollen assemblages (Figure 5(a)). Fernlands, in particular could not be distinguished from any other predominantly herbaceous community, on this basis. Even though some fern spores, for example the Pteridium-type, seemed to be more abundant in fernlands than in other communities (Figure 3) other spore types occurred in the soils of several of the sites surveyed.

In contrast to the situation for fernlands, where no reliable palynological indicator for their occurrence was identified, the occurrence of palm swamps could be detected by the presence of Mauritia pollen (restricted to Mauritia swamps), and that of grasslands by the presence of Stegolepis pollen, which only grows in high densities in grassland mires. However, Mauritia pollen has a very limited capacity for dispersal, being absent in soils located just a few hundred meters from the community [68]. 
Stegolepis also seems to produce/disperse very little pollen. The low dispersal capacity of these two pollen types begs the question as to whether some swamps or grasslands with very low densities of Mautitia or Stegolepis, respectively, could go unnoticed in any given sedimentary record. To test this, additional studies considering pollen dispersal in spatial transects should be performed in the study area.

\subsection{Utility of Modern Analogues for the Description of Past Vegetation Changes and Implications for the Paleoecology of Gran Sabana}

Within the Gran Sabana, paleoecological data has suggested that gallery forests declined during the Holocene. Climate change and fire have been identified as the major drivers of vegetation changes [2,72]. Nevertheless, although today the Gran Sabana is the most intensively studied area in Venezuela from the paleoecological point of view (with more than 15 Holocene sedimentary records studied), the causes and processes that underlie forest degradation in the region still are not well understood. One of the aspects that we need to improve is the characterization of former woody communities, since this is central to our understanding as to why they have been so vulnerable to climate change and fire. In this regard, pollen rain representation and the use of a gradient of vegetation openness for the interpretation of paleoecological data seem to constitute effective tools for the identification of different states of forest disturbance.

The history of some sites described in this study is similar to that reported previously by other authors, such as for example, the development of Quebrada Pacheco Swamp, where an open gallery forest has been apparently substituted by a Mauritia palm swamp in the last millennium (Figure 7). Our data also show the substitution of a former woody community (similar to a savanna-forest border or a "matorral") by a treeless savanna after local fires in Ariwe Fernland (Figure 6). However, the woody communities and forests present at the base of both records examined here were far from being healthy mature forests, and their high vulnerability could be explained in the light of a long history of disturbances. The paleoecological studies done in the Gran Sabana support this last idea, as they show that the process of forest degradation started well before the last two millennia, and thus previous to extensive human impact in this region, probably since the mid Holocene and even the early Holocene [1,4-6].

Finally it is important to highlight that our paleoecological data were able to distinguish between sites that have remained relatively stable, at least over the last few centuries, and sites that have undergone changes. An example of the first of these is El Oso Forest, where the current savanna-forest border has experienced few modifications. Other places, such as Colonia Fernland show a very different picture. There, the tall forests have undergone an expansion in the last millennium, even though indicators of local fire events suggest a more frequent/ intense regime of fire over the last few hundred years. These results underline the importance of selecting study areas that are subject to different environmental conditions, in order to attain a broader picture of long-term landscape changes.

\section{Conclusions and Recommendations}

Pollen rain studies have traditionally focused on searching for distinctive pollen assemblages as unequivocal indicators of the occurrence of former plant communities in sedimentary records. However, when paleoecology is used for assessing the history of fragmentation processes in the landscape, this approach gives us an incomplete picture. Firstly, because after fragmentation a myriad of transient communities are created, some of which represent intermediate states between discrete communities (regarding species composition or even structure), and secondly because complex spatial mosaics also develop, a dimension that is not easily taken into account in conventional interpretations of paleoecological data. Assessing issues such as the historical processes of human-made ecosystem fragmentation and/or the long-term effects of fire in tropical forest dynamics require the palynological characterization of transitional communities and the evaluation of palynological signals related to the degree of openness of vegetation. In this study, we have shown that establishing a gradient of openness from closed forests, to secondary forests and gallery forest patches, savanna-forest borders and open herbaceous communities, is helpful for the interpretation of former pollen assemblages found in sedimentary records and soil profiles. In this regard, this investigation has enabled us to obtain a better picture of the relationship between standing communities and pollen rain in soils, especially considering, communities that were not included in previous studies. However, the high complexity and diversity of plant communities observed nowadays in the vegetation mosaics of upland Guayana has not been completely covered here. Additional research, examining other environmental gradients present in the study area is still needed, and hence future studies will be oriented towards a broader description of forest formations in the Gran Sabana along altitudinal, rainfall and disturbance gradients, as well as the study of pollen rain in communities not included in the present contribution, such as the Guayana shrublands. 


\section{Acknowledgements}

Thanks to the people of Kavanayén, San Juan and San Rafael de Kamoirán, Kumaracapay, San Ignacio de Yuruaní and Waramasén for providing access for sample collection. This investigation was funded by FONACIT (G-2005000514) and by a Ph.D. scholarship from the same fund. Thanks also to Eduardo Zambrano and Carlos Méndez for their help with the fieldwork. We are grateful to INPARQUES for providing the necessary permits on behalf of "Proyecto Riesgo" and to Estación Científica Parupa (CVG) and EDELCA that gave valuable logistic support.

\section{REFERENCES}

[1] V. Rull, "Holocene Global Warming and the Origin of the Neotropical Gran Sabana in the Venezuelan Guayana," Journal of Biogeography, Vol. 34, No. 2, 2007, pp. 279288. doi:10.1111/j.1365-2699.2006.01620.x

[2] V. Rull, "New Paleoecological Evidence on the Role of Fire in the Gran Sabana (Venezuelan Guayana), and Implications for Early Human Occupation," Vegetation History and Archaeobotany, Vol. 18, No. 3, 2009, pp. 219224. doi:10.1007/s00334-008-0195-1

[3] E. Montoya, V. Rull, S. Nogué and W. Díaz, "Paleoecología de la Gran Sabana, SE Venezuela: Análisis Preliminar de Polen y Microcarbones en la Laguna Encantada," Collectanea Botanica, Vol. 28, 2009, pp. 65-79.

[4] E. Montoya, V. Rull, N. D. Stansell, M. B. Abbott, S. Nogué, B. W. Bird and W. Díaz, "Forest-Savanna-Morichal Dynamics in Relation to Fire and Human Occupation in the Southern Gran Sabana (SE Venezuela) during the Last Millenia," Quaternary Research, Vol. 76, No. 3, 2011, pp. 335-344. doi:10.1016/j.yqres.2011.06.014

[5] E. Montoya, V. Rull, N. D. Stansell, B. W. Bird, S. Nogué, T. Vegas-Vilarrúbia, M. B. Abbott and W. Díaz, "Vegetation Changes in the Neotropical Gran Sabana (Venezuela) around the Younger Dryas Chron," Quarternary Science, Vol. 26, No. 2, 2011, pp. 207-218.

[6] E. Montoya, V. Rull and S. Nogué, "Early Human Occupation and Land Use Change near the Boundary of the Orinoco and the Amazon Basins (SE Venezuela): Palynological Evidence from El Paují Record," Palaeogeography, Palaeoclimatology, Palaeoecology, Vol. 310, No. 3-4, 2011, pp. 413-426. doi:10.1016/j.palaeo.2011.08.002

[7] A. Leal, "Historia Holocena de la Vegetación y el Fuego en Bordes Sabana-Bosque y Turberas de la Gran Sabana, Guayana Venezolana," Ph.D. Thesis, Universidad Simón Bolívar, Caracas-Venezuela, 2010.

[8] V. Rull, "Contribución a la Paleoecología de Pantepui y la Gran Sabana (Guayana Venezolana): Clima, Biogeografía y Ecología," Scientia Guaianae, Vol. 2, 1991, pp. 1133.

[9] V. Rull, "A Palynological Record of a Secondary Succession after Fire in the Gran Sabana, Venezuela," Journal of
Quaternary Science, Vol. 14, No. 2, 1999, pp. 137-152. doi:10.1002/(SICI)1099-1417(199903)14:2<137::AID-JQ S413>3.0.CO;2-3

[10] L. Delgado, H. Castellanos and M. Rodríguez, "La Vegetación," In: Biodiversidad del Parque Nacional Canaima, The Nature Conservancy, Caracas, 2009.

[11] J. Rodgers and S. P. Horn, "Modern Pollen Spectra from Costa Rica," Palaeogeography, Palaeoclimatology, Palaeoecology, Vol. 124, No. 1-2, 1996, pp. 53-71. doi:10.1016/0031-0182(96)00004-1

[12] C. Weng, M. Bush and M. Silman, "An Analysis of Modern Pollen Rain on an Elevational Gradient in Southern Perú," Journal of Tropical Ecology, Vol. 20, No. 1, 2004, pp. 113-124. doi:10.1017/S0266467403001068

[13] L. M. Kennedy, S. Horn and K. Orvis, "Modern Pollen Spectra from the Highlands of the Cordillera Central, Dominican Republic," Review of Palaeobotany and $\mathrm{Pa}$ lynology, Vol. 137, No. 1-2, 2005, pp. 51-68. doi:10.1016/j.revpalbo.2005.08.007

[14] M. Moscol-Olivera, J. F, Duivenvoorden and H. Hooghiemstra, "Pollen Rain and Pollen Representation across a Forest-Páramo Ecotone in Northern Ecuador," Review of Palaeobotany and Palynology, Vol. 157, No. 3-4, 2009, pp. 285-300. doi:10.1016/i.revpalbo.2009.05.008

[15] H. Niemann, C. Brunschön and H. Behling, "Vegetation/Modern Pollen Rain Relationship along an Altitudinal Transect between 1920 and 3185 m a.s.l. in the Podocarpus National Park Region, Southeastern Ecuadorian Andes," Review of Palaeobotany and Palynology, Vol. 159, No. 1-2, 2010, pp. 69-80. doi:10.1016/j.revpalbo.2009.11.001

[16] N. Jantz, J. Homeier, S. León-Yanez, A. Moscoso and H. Behling, "Trapping Pollen in the Tropics-Comparing Modern Pollen Rain Spectra of Different Pollen Traps and Surface Samples across Andean Vegetation Zones," Review of Palaeobotany and Palynology, Vol. 193, 2013, pp. 57-69. doi:10.1016/j.revpalbo.2013.01.011

[17] L. E. Urrego, G. Bernal and J. Polanía, "Comparison of Pollen Distribution Patterns in Surface Sediments of a Colombian Caribbean Mangrove with Geomorphology and Vegetation," Review of Palaeobotany and Palynology, Vol. 156, No. 3-4, 2009, pp. 358-375. doi:10.1016/i.revpalbo.2009.04.004

[18] L. E. Urrego, C. González, G. Urán and J. Polanía, "Modern Pollen Rain in Mangroves from San Andres Island, Colombian Caribbean," Review of Palaeobotany and Palynology, Vol. 162, No. 2, 2010, pp. 168-182. doi:10.1016/j.revpalbo.2010.06.006

[19] J. Muller, "Palynology of Recent Orinoco Delta and Shelf Sediments: Reports of the Orinoco Shelf Expedition," Micropaleontolgy, Vol. 5, No. 1, 1959, pp. 1-32. doi: $10.2307 / 1484153$

[20] M. Bush, "On the Interpretation of Fossil Poaceae Pollen in the Lowland Humid Neotropics," Palaeogeography, Palaeoclimatology, Palaeoecology, Vol. 177, No. 1-2, 2002, pp. 5-17. doi:10.1016/S0031-0182(01)00348-0

[21] M. Bush and R. Rivera, "Reproductive Ecology and Pollen Representation among Neotropical Trees," Global 
Ecology \& Biogeography, Vol. 10, No. 4, 2001, pp. 359367. doi:10.1046/j.1466-822X.2001.00247.x

[22] G. Domínguez-Vásquez, G. Islebe and R. VillanuevaGutiérrez, "Modern Pollen Deposition in Lacandon Forest, Chiapas, Mexico," Review of Palaeobotany and Palynology, Vol. 131, No. 1-2, 2004, pp. 105-116. doi:10.1016/j.revpalbo.2004.03.004

[23] J. C. Berrío, H. Hooghiemstra, R. Marchant and O. Rangel, "Late-Glacial and Holocene History of the Dry Forest Area in the South Colombian Cauca Valley," Journal of Quaternary Science, Vol. 17, No. 7, 2002, pp. 667682.doi:10.1002/jqs.701

[24] J. C. Berrío, H. Hooghiemstra, H. Behling, P. Botero and K. Van der Borg, "Late Quaternary Savanna History of the Colombian Llanos Orientales from Lagunas Chenevo and Mozambique: A Transect Synthesis," The Holocene, Vol. 12, No. 1, 2002, pp. 35-48.

[25] C. Hofmann, "Pollen Distribution in Sub-Recent Sedimentary Environments of the Orinoco Delta (Venezuela) -An Actuo-Palaeobotanical Study," Review of Palaeobotany and Palynology, Vol. 119, No. 3-4, 2002, pp. 191217. doi:10.1016/S0034-6667(01)00141-5

[26] W. Gosling, F. Mayle, N. Tate and T. Killeen, "Modern Pollen-Rain Characteristics of Tall Terra Firme Moist Evergreen Forest, Southern Amazonia," Quaternary Research, Vol. 64, No. 3, 2005, pp. 284-297. doi:10.1016/i.yqres.2005.08.008

[27] W. D. Gosling, F. E. Mayle, N. J. Tate and T. J. Killeen, "Differentiation between Neotropical Rainforest, Dry Forest, and Savannah Ecosystems by Their Modern Pollen Spectra and Implications for the Fossil Pollen Record," Review of Palaeobotany and Palynology, Vol. 153, No. 1-2, 2009, pp. 70-85. doi:10.1016/i.revpalbo.2008.06.007

[28] M. J. Burn, F. E. Mayle and T. J. Killeen, "Pollen-Based Differentiation of Amazonian Rainforest Communities and Implications for Lowland Palaeoecology in Tropical South America," Palaeogeography, Palaeoclimatology, Palaeoecology, Vol. 295, No. 1-2, 2010, pp. 1-18. doi:10.1016/i.palaeo.2010.05.009

[29] T. Ortuño, M. P. Ledru, R. Cheddadi, A. Kuentz, C. Favier and S. Beck, "Modern Pollen Rain, Vegetation and Climate in Bolivian Ecoregions," Review of Palaeobotany and Palynology, Vol. 165, No. 1-2, 2011, pp. 61-74. doi:10.1016/j.revpalbo.2011.02.004

[30] H. Jones, F. Mayle, R. T. Pennington and T. J. Killeen, "Characterisation of Bolivian Savanna Ecosystems by Their Modern Pollen Rain and Implications for Fossil Pollen Records," Review of Palaeobotany and Palynology, Vol. 164, No. 3-4, 2011, pp. 223-237. doi:10.1016/j.revpalbo.2011.01.001

[31] R. Marchant, L. Almeida, H. Behling, J. C. Berrio, M. Bush, A. Cleef, J. Duivenvoorden, M. Kappelle, P. De Oliveira, A. T. de Oliveira-Filho, S. Lozano-Garćia, H. Hooghiemstra, M. P. Ledru, B. Ludlow-Wiechers, V. Markgraf, V. Mancini, M. Paez, A. Prieto, O. Rangel, M. L. Salgado-Labouriau, et al., "Distribution and Ecology of Parent Taxa of Pollen Lodged within the Latin Ameri- can Pollen Database," Review of Palaeobotany and Palynology, Vol. 121, No. 1, 2002, pp. 1-75. doi:10.1016/S0034-6667(02)00082-9

[32] L. Hernández, “Clima,” In: I. N. Dezeo, Ed., Ecología de la Altiplanicie de la Gran Sabana (Guayana Venezolana) Consejo Nacional de Investigaciones Científicas y Tecnológicas, 1994, pp. 25-33.

[33] O. Huber and G. Febres, "Ecological Guide of the Gran Sabana," The Nature Conservancy, Caracas, 2000.

[34] H. Fölster, "Stability of Forest Ecosystems in the Humid Tropics," Interciencia, Vol. 19, No. 6, 1994, pp. 291-296.

[35] N. Dezzeo and H. Fölster, "Los Suelos," In: I. N. Dezzeo Ed., Ecología de la altiplanicie de la Gran Sabana (Guayana Venezolana), Consejo Nacional de Investigaciones Científicas y Tecnológicas, 1994, pp. 1-24.

[36] B. Sletto, "The Knowledge that Counts: Institutional Identities, Policy Science, and the Conflict over Fire Management in the Gran Sabana, Venezuela," World Development, Vol. 36, No. 10, 2008, pp. 1938-1955.

doi:10.1016/j.worlddev.2008.02.008

[37] I. Rodriguez and B. Sletto, “Apök Hace Feliz a Patá. Desafíos y Sugerencias Para Una Gestión Intercultural del Fuego en la Gran Sabana," Antropologica, Vol. 29, No. 3, 2009, pp. 121-129.

[38] B. Bilbao, A. Leal, C. Méndez and M. Delgado, "The Role of Fire in Vegetation Dynamics of Upland Savannas of the Venezuelan Guayana," In: M. A. Cochrane, Ed., Tropical Fire Ecology: Climatic Change, Land Use and Ecosystem Dynamics, Springer-Praxis, Berlin, 2009.

[39] B. Bibiana, A. Leal and C. Méndez, "Indigenous Use of Fire and Forest Loss in Canaima National Park, Venezuela. Assessment and Tools for Alternative Strategies of Fire Management in Pemón Indigenous Land," Human Ecology, Vol. 38, No. 5, 2010, pp. 663-673. doi:10.1007/s10745-010-9344-0

[40] L. Hernández, "Bosques,” In: I. N. Dezzeo, Ed., Ecología de la altiplanicie de la Gran Sabana (Guayana Venezolana), Consejo Nacional de Investigaciones Científicas y Tecnológicas, 1994, pp. 1-205.

[41] L. Hernandéz, "Ecología de la Gran Sabana II," Scientia Guaianae, Vol. 9, 1999.

[42] O. Huber, "La Vegetación de la Cuenca del Río Caroní," Interciencia, Vol. 11, 1986, pp. 301-310.

[43] N. Dezzeo and N. Chacón, "Carbon Nutrients Loss in Aboveground Biomass along a Fire Induced Forest-Savanna Gradient in the Gran Sabana, Southern Venezuela," Forest Ecology and Management, Vol. 209, No. 3, 2005, pp. 343-352. doi:10.1016/j.foreco.2005.02.008

[44] E. Sanoja, "Lista Dendrológica de los Bosques Montanos de la Escalera, Sierra de Lema, Estado Bolívar, Venezuela," Acta Botanica Venezuelica, Vol. 32, No. 1, 2009, pp. 79-111.

[45] C. Durán, A. Reif and L. Hernández, "Disturbios a Pequeña Escala en un Bosque Tropical Montano de Guayana: Caracterización de Claros en la Sierra de Lema, Venezuela," Interciencia, Vol. 36, 2011, pp. 272-280.

[46] O. Huber, "Savannas and Related Vegetation Types of the 
Guayana Shield Region in Venezuela," In: G. Sarmiento, Ed., Las Sabanas Americanas: Aspectos de su Biogeografía, Ecología y Utilización, Fondo Editorial Acta Científica Venezolana, Caracas, 1990, pp. 57-97.

[47] O. Huber, "La Vegetación," In: I. N. Dezzeo, Ed., Ecología de la altiplanicie de la Gran Sabana (Guayana Venezolana), Consejo Nacional de Investigaciones Científicas y Tecnológicas, 1994, pp. 95-159.

[48] O. Huber, "Herbaceous Ecosystems on the Guayana Shield, a Regional Overview," Journal of Biogeography, Vol. 33, No. 3, 2006, pp. 464-475.

[49] N. Ramírez, N. Dezzeo and N. Chacón, "Floristic Composition, Plant Species Abundance, and Soil Properties of Montane Savannas in the Gran Sabana, Venezuela," Flora-Morphology, Distribution, Functional Ecology of Plants, Vol. 202, No. 4, 2007, pp. 316-327. doi:10.1016/j.flora.2006.07.005

[50] B. Bilbao, A. Leal, C. Méndez, A. Osío and Z. Hasmy, "Significado Ecológico de las Sabanas y Zonas de Transición Sabana-Bosque en el Mosaico de Vegetación de la Gran Sabana. Recomendaciones Para el Manejo y la Recuperación de Áreas Degradadas por el Fuego,” In: F. Herrera and E. I. Herrera, Eds., Experiencias de Restauración Ecológica en Venezuela en las Últimas Décadas, Ediciones IVIC, Caracas, 2012.

[51] Z. Baruch, "Vegetation-Environment Relationships and Classification of the Seasonal Savannas in Venezuela," Flora-Morphology, Distribution, Functional Ecology of Plants, Vol. 200, No. 1, 2005, pp. 49-64. doi:10.1016/j.flora.2004.06.001

[52] L. Hernández and H. Fölster, "La Vegetación en Ransición," In: Ecología de la Gran Sabana I, Consejo Nacional de Investigaciones Científicas y Tecnológicas, 1994.

[53] O. Huber, "Introduction," In: J. Steyermark and P. Berry, Eds., Flora of the Venezuelan Guayana, Missouri Botanical Garden, St. Louis, 1995.

[54] K. Faegri and J. Iversen, "Textbook of Pollen Analysis," 3rd Edition, Hafner Publishing, New York, 1981.

[55] E. Traverse, "Paleopalynology," 2nd Edition, Springer, Berlin, 2007.

[56] G. M. MacDonald, "Non-Aquatic Quaternary," In: J. Jansonius and D. C. McGregor, Eds., Palynology, Principles and Applications, American Association of Stratigraphic Palynologists Foundation, 1996, pp. 879-910.

[57] L. Maher, "Statistics for Microfossil Concentration Measurements Employing Samples Spiked with Marker Grains," Review of Palaeobotany and Palynology, Vol. 32, No. 2-3, 1981, pp. 153-191. doi:10.1016/0034-6667(81)90002-6

[58] A. Leal, E. Raimúndez, J. C. Berrío and B. Bilbao, “A Pollen Key of Premontane Woody and Herbaceous Communities in the Upland Savannas of Guayana, Southeast Venezuela," Palynology, Vol. 35, No. 2, 2011, pp. 226-
266.

[59] V. Rull, "An Illustrated Key for the Identification of Pollen from Pantepui and the Gran Sabana (Eastern Venezuelan Guayana)," Palynology, Vol. 27, No. 1, 2003, pp. 99-133. doi:10.2113/27.1.99

[60] L. Herrera and L. Urrego, "Atlas de polen de Plantas Útiles y Cultivables de la Amazonia Colombiana," Estudios en la Amazonía Colombiana, Tropenbos, 1996.

[61] P. Colinvaux, P. De Oliveira and J. Moreno, “Amazon Pollen Manual and Atlas," Harwood Academic Publishers, Amsterdam, 1999.

[62] R. H. Tschudy and B. D. Tschudy, "Modern Fern Spores of Rancho Grande, Venezuela," Acta Botánica Venezuelica, Vol. 1, No. 1, 1965, pp. 9-73.

[63] M. Bush and C. Weng, "Introducing a New (Freeware) Tool for Palynology," Journal of Biogeography, Vol. 34, No. 3, 2007, pp. 377-380. doi:10.1111/j.1365-2699.2006.01645.x

[64] K. S. Bawa, "Plant Pollinator Interactions in Tropical Rain Forest," Annual Reviews of Ecology and Systematics, Vol. 21, No. 1, 1990, pp. 399-422. doi:10.1146/annurev.es.21.110190.002151

[65] G. Erdtman, "Pollen Analysis," 3rd Edition, Hafner Publishing, New York, 1981.

[66] L. Schüler and H. Behling, "A New Method to Investigate Past Grassland Dynamics in South America Based on Poaceae Pollen Grain Size," Quaternary International, Vol. 279-280, 2011, p. 439.

[67] V. Rull, "Biogeographical and Evolutionary Considerations on Mauritia (Arecaceae), Based on Palynological Evidence," Review of Palaeobotany and Palynology, Vol. 100, No. 1-2, 1998, pp. 109-122. doi:10.1016/S0034-6667(97)00060-2

[68] A. Leal and B. Bilbao, "Cambios de Vegetación Durante el Holoceno Tardío en un Morichal de los Llanos del Orinoco, Venezuela," Acta Botanica Venezuelica, Vol. 34, No, 2, 2011, pp. 237-256.

[69] V. González, "Los Morichales de los Llanos Orientales. Un Enfoque Ecológico," Serie Cuadernos Corpoven, Caracas, 1987.

[70] M. Bush, "On the Interpretation of Fossil Poaceae Pollen in the Lowland Humid Tropics," Palaeogeography, $\mathrm{Pa}$ laeoclimatology, Palaeoecology, Vol. 177, No. 1-2, 2002, pp. 5-17.doi:10.1016/S0031-0182(01)00348-0

[71] J. C. Berrío, H. Hooghiemstra, H. Behling and K. Van der Borg, "Late Holocene History of Savanna Gallery Forest from Carimagua Area, Colombia," Review of Palaeobotany and Palynology, Vol. 111, No. 3-4, 2000, pp. 295308. doi:10.1016/S0034-6667(00)00030-0

[72] E. Montoya and V. Rull, "Gran Sabana Fires (SE Venezuela): A Paleoecological Perspective," Quaternary Science Reviews, Vol. 30, No. 23-24, 2011, pp. 3430-3444. doi:10.1016/j.quascirev.2011.09.005 


\section{Appendix 1}

List of the pollen types identified in the $\mathbf{3 0}$ surface soil samples analyzed. The pollen types included in the percentage diagram shown in Figure 3 are marked with an asterix (*).

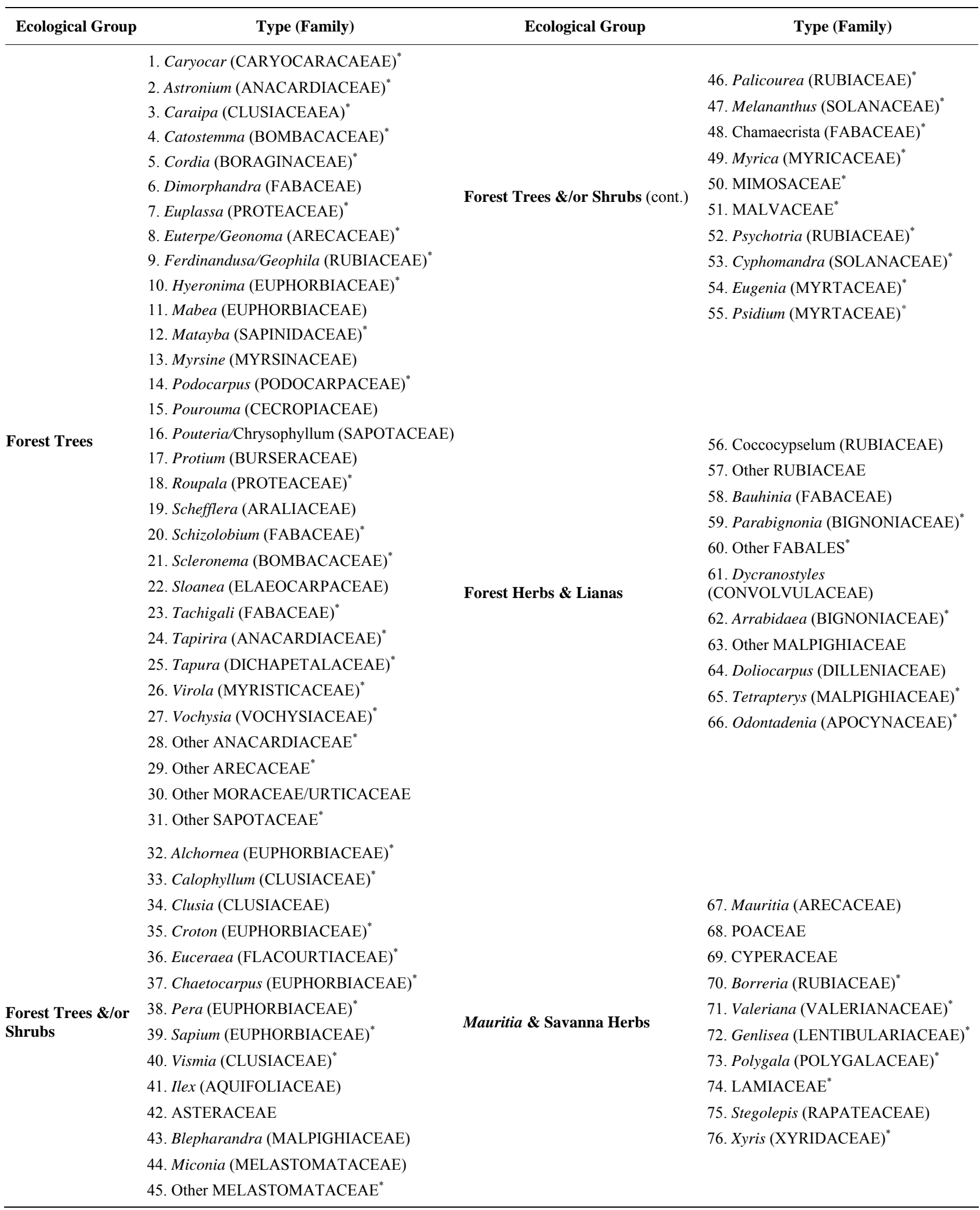




\section{Appendix 2}

Main pollen assemblages found in the four sedimentary records studied. The interpretation of vegetation changes as a result of the joint analysis of past and present pollen assemblages is also shown.

\begin{tabular}{|c|c|c|c|c|}
\hline Record & Stratigraphy & Description of palynological assemblages & Charcoal & $\begin{array}{c}\text { Interpretation of } \\
\text { vegetation changes }\end{array}$ \\
\hline \multirow{4}{*}{$\begin{array}{l}\text { Ariwe } \\
\text { Fernland }\end{array}$} & \multirow{4}{*}{$\begin{array}{l}\text { Organic clay, } \\
\text { changing } \\
\text { gradually from } \\
\text { light grey to } \\
\text { dark grey, from } \\
\text { the bottom to } \\
\text { the top. }\end{array}$} & $\begin{array}{l}\text { - } 190 \text { - } 90 \mathrm{~cm}(3.400-1.200 \mathrm{yr} . \mathrm{BP}) \text {. Around } 30 \%-40 \% \text { of } \\
\text { pollen from woody elements and around } 60 \% \text { from savanna } \\
\text { elements. Dominant woody elements were Dimorphandra, } \\
\text { Astronium, Eucearea, Moraceae/Urticaceae, Blepharandra and } \\
\text { Miconia. Poaceae } 20 \% \text { and Cyperaceae } 15 \% \text {. }\end{array}$ & $\begin{array}{l}\text { High values, similar to } \\
\text { present. }\end{array}$ & $\begin{array}{l}\text { Very open gallery forest } \\
\text { (matorral?), similar to current } \\
\text { savanna forest borders. }\end{array}$ \\
\hline & & $\begin{array}{l}-90-50 \mathrm{~cm}(1.200-850 \mathrm{yr} \text {. BP }) \text {. Most forest types disappeared. } \\
\text { Pollen from woody elements represented less than } 5 \% \text { of total } \\
\text { pollen, while pollen from savanna herbs increased to more than } \\
\text { 95\%. Ferns, mainly Lycopodium and Pteridium type spores, } \\
\text { also increased. }\end{array}$ & $\begin{array}{l}\text { Lower values than } \\
\text { previous time zone. }\end{array}$ & $\begin{array}{l}\text { Treeless savanna. Probably with } \\
\text { some Pteridium ferns } \\
\text { developing. Similar to current } \\
\text { fernlands. }\end{array}$ \\
\hline & & $\begin{array}{l}\text { - } 50 \text { - } 45 \mathrm{~cm} \text { ( } 800 \mathrm{yr} \text {. BP). Re-appearance of pollen from some } \\
\text { woody elements reaching percentages around } 20 \% \text { : mainly } \\
\text { Roupala, Ilex, Calophyllum. Pteridium-type spores increased } \\
\text { just before the increase of woody elements. }\end{array}$ & $\begin{array}{l}\text { Minimal charcoal } \\
\text { recorded. }\end{array}$ & $\begin{array}{l}\text { Fernland with some scrubby } \\
\text { elements developing. Similar to } \\
\text { current fernlands. }\end{array}$ \\
\hline & & $\begin{array}{l}\text { - } 45 \text { - } 0 \text { ( } 800 \text { yr. BP-present }) \text { : woody elements disappeared, and } \\
\text { savanna herbs increased to more than } 90 \% \text { of the pollen sum. } \\
\text { Fern spores have similar abundances to previous time zones }\end{array}$ & Charcoal increasing. & $\begin{array}{l}\text { Treeless savanna. Probably with } \\
\text { some Pteridium ferns } \\
\text { developing. Present vegetation } \\
\text { was established. }\end{array}$ \\
\hline $\begin{array}{l}\text { El Oso } \\
\text { Forests }\end{array}$ & $\begin{array}{l}\text { Silty-sandy } \\
\text { profile, } \\
\text { changing } \\
\text { gradually from } \\
\text { pink to dark } \\
\text { ground, from } \\
\text { the bottom to } \\
\text { the top. }\end{array}$ & $\begin{array}{l}\text { - No major changes were observed in the proportions of forest } \\
\text { and savanna pollen over the last } 500 \text { yr BP: forest elements } \\
\text { accounted for around } 40 \%-50 \% \text {, and savanna herbs around } \\
50 \%-60 \% \text {. Main pollen types were Dimorphandra, } \\
\text { Pourouma, Schefflera and Miconia. Around } 30 \%-40 \% \text { of } \\
\text { pollen was from Poacea and } 10 \% \text { - } 20 \% \text { from the Cyperaceae, } \\
\text { with the highest abundance in the deepest half of the sequence. }\end{array}$ & $\begin{array}{l}\text { Charcoal very low from } \\
80-20 \mathrm{~cm} \text {, and then } \\
\text { increasing towards the } \\
\text { top of the sequence. }\end{array}$ & $\begin{array}{l}\text { The current savanna-forest } \\
\text { border has remained quite stable } \\
\text { over the last five centuries. }\end{array}$ \\
\hline \multirow{3}{*}{$\begin{array}{l}\text { Quebrada } \\
\text { Pacheco } \\
\text { Swamp }\end{array}$} & \multirow{2}{*}{$\begin{array}{l}\text { Black peat in } \\
\text { the upper } 100 \\
\mathrm{~cm} \text { and dark } \\
\text { grey to light } \\
\text { clay in the } \\
\text { lower } 90 \mathrm{~cm} .\end{array}$} & $\begin{array}{l}\text { - } 190-180 \mathrm{~cm} \text { (ca. } 1.000 \mathrm{yr} \text { BP). Gallery forest pollen types } \\
\text { represented around } 60 \% \text { of the pollen sum, with Protium, } \\
\text { Schefflera, Moraceae/Urticaceae, Euceraea, Asteraceae, } \\
\text { Clusia and Cyrilla being the most abundant. Poaceae and } \\
\text { Cyperaceae pollen contributed about } 30 \% \text { and } 15 \% \text {, } \\
\text { respectively. Algae, such as Debarya and other zigospores } \\
\text { were present, as well as aquatics, suggesting a flooding regime. }\end{array}$ & $\begin{array}{l}\text { Charcoal }>100 \text { um } \\
\text { abundant but not as } \\
\text { high as in the present. }\end{array}$ & $\begin{array}{l}\text { A community similar to current } \\
\text { savanna-forest borders or open } \\
\text { gallery forest developed in the } \\
\text { area. The forest was seasonally } \\
\text { flooded. }\end{array}$ \\
\hline & & $\begin{array}{l}-180-80 \mathrm{~cm}(1.000-500 \mathrm{yr} \text { BP }) \text {. Gallery forest pollen types } \\
\text { decreased to less than } 10 \% \text { and pollen from the Poaceae } \\
\text { increased to more than } 80 \% \text {. Hence, the savanna herbs group } \\
\text { represented more than } 90 \% \text { of the pollen sum. Aquatics and } \\
\text { algae remained at high values. }\end{array}$ & $\begin{array}{l}\text { Charcoal }>100 \text { um } \\
\text { abundant but not as high } \\
\text { as in the present. }\end{array}$ & $\begin{array}{l}\text { A grassy mire developed in the } \\
\text { study site. }\end{array}$ \\
\hline & \multirow{4}{*}{$\begin{array}{l}\text { Clayey soil } \\
\text { profile, } \\
\text { changing } \\
\text { gradually from } \\
\text { light red brown } \\
\text { to dark } \\
\text { red-brown, } \\
\text { from the } \\
\text { bottom to the } \\
\text { top. }\end{array}$} & $\begin{array}{l}\text { - } 80-0 \mathrm{~cm} \text { ( } 500 \mathrm{yr} \text { BP-present). Dominance of savanna herbs } \\
\text { was maintained, but Mauritia pollen appeared and increased in } \\
\text { abundance in a sustained way until the present. }\end{array}$ & $\begin{array}{l}\text { Charcoal increased } \\
\text { gradually }\end{array}$ & $\begin{array}{l}\text { A Mauritia swamp with a scarce } \\
\text { woody component developed in } \\
\text { the study area. }\end{array}$ \\
\hline \multirow{3}{*}{$\begin{array}{l}\text { Colonia } \\
\text { Fernland }\end{array}$} & & $\begin{array}{l}\text { - } 90 \text { - } 80 \mathrm{~cm} \text { ( } 1.400-1.200 \mathrm{yr} \text { BP). Savanna herbs represented } \\
\text { almost } 40 \% \text { of the pollen sum. Poaceae and Cyperaceae } \\
\text { contributed around } 25 \% \text { and } 15 \% \text { respectively. Fabaceae, } \\
\text { Asteraceae and Alchornea, together with Euterpe/Geonoma, } \\
\text { Protium and Schefflera were the most abundant pollen types. } \\
\text { - } 80-35 \mathrm{~cm}(1.200-500 \mathrm{yr} \text { BP) Pollen types from forest } \\
\text { elements increased to more than } 75 \% \text { of the pollen sum. Pollen } \\
\text { from savanna herbs dramatically decreased in abundance, at the } \\
\text { same time as Alchornea and Schefflera pollen increased. }\end{array}$ & $\begin{array}{l}\text { Charcoal abundance at a } \\
\text { minimum for the record. } \\
\text { Charcoal particles } \\
\text { increased in abundance. }\end{array}$ & $\begin{array}{l}\text { The savanna-forest border was } \\
\text { more open than today. Pollen } \\
\text { assemblage is typical of } \\
\text { savanna-forest borders studied in } \\
\text { the region. } \\
\text { The montane forest expanded to } \\
\text { proportions similar to those of } \\
\text { the present. }\end{array}$ \\
\hline & & $\begin{array}{l}\text { - At } 35 \mathrm{~cm}(500 \mathrm{yr} \mathrm{BP}) \text {. Pollen from forest elements decreased } \\
\text { (by around } 65 \%) \text { and that of savanna herbs increased } \\
\text { (by around } 35 \% \text { ). }\end{array}$ & $\begin{array}{l}\text { No significant changes } \\
\text { in the charcoal record. }\end{array}$ & $\begin{array}{l}\text { The forest retreated, or the forest } \\
\text { was more open than today } \\
\text { (similar to secondary forests } \\
\text { and/or fallows). }\end{array}$ \\
\hline & & $\begin{array}{l}-35-0 \mathrm{~cm} \text { ( } 500 \mathrm{yr} \text { BP-present). Pollen from forest elements } \\
\text { increased again and savanna herbs contributed less than } 10 \% \text { of } \\
\text { the pollen sum. From then to the present, forest vs. savanna } \\
\text { types have fluctuated, with savanna herb pollen values less than } \\
25 \% \text { and forest pollen types contributing over } 75 \% \text { of the } \\
\text { pollen sum. }\end{array}$ & $\begin{array}{l}\text { Charcoal particles } \\
\text { increased in abundance } \\
\text { in a sustained way. }\end{array}$ & $\begin{array}{l}\text { The current tall forest recovered } \\
\text { again. }\end{array}$ \\
\hline
\end{tabular}

